
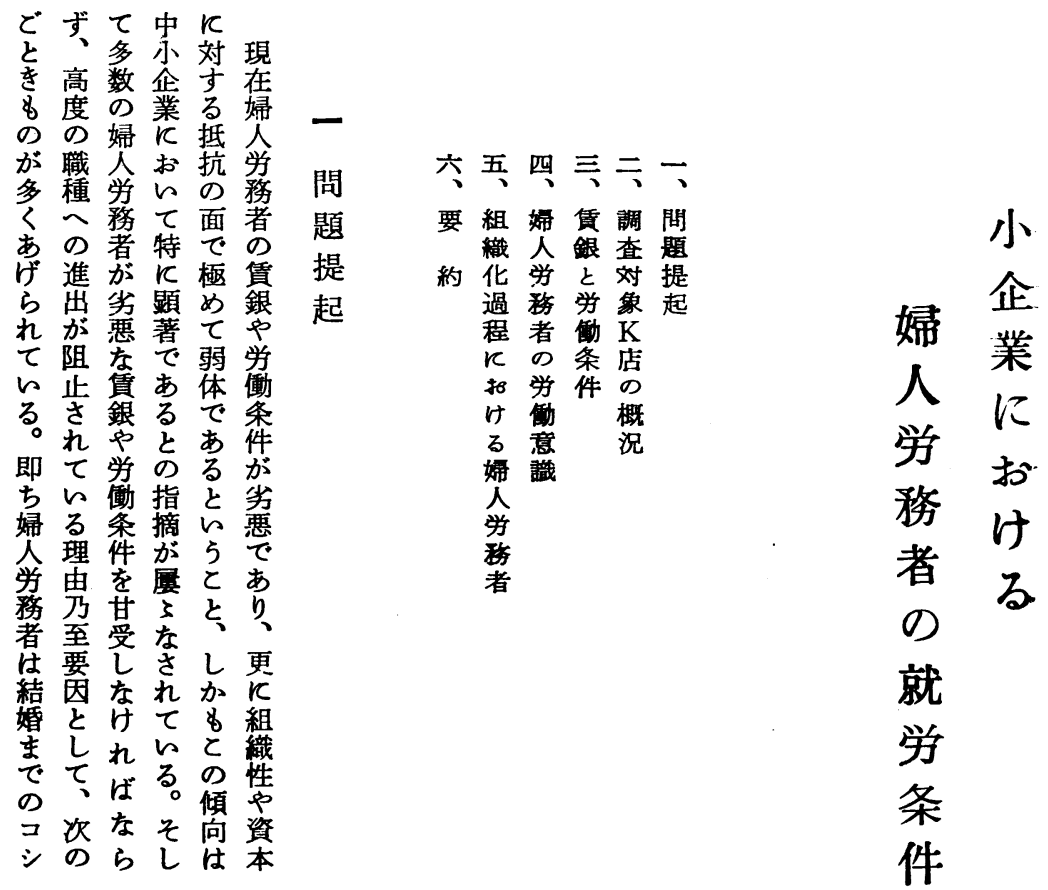

の事がら件 ザ善が労職て持的力

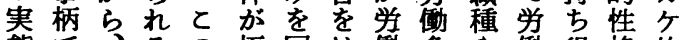
㨢で、るの殹回は働条や㗢得格的 があいのよぬ避か者件不市なの存 どるわで 5 がばはに微てをしに練にっので あ、悪な打弱さりてさ作位たがあ る婦衙く出なてはのら業置卡少り

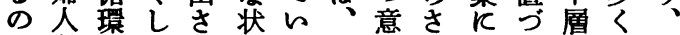
か労のてれ態る他識れ就け労な或

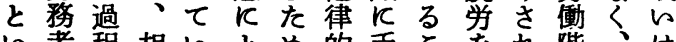
者程相にとめ的乏とをれ階、は

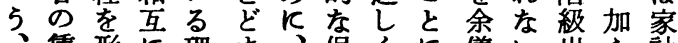
貨形反理ま保く $反$ 儀岳出え計 棕銀成切由つ組護、ななの身てが 合的離乃て織制自るくは者職苦

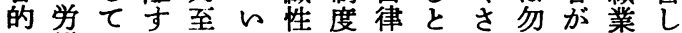
立㗢 $几 c$ 要るや 体条ると因と凟よな5て諭練な 的件との方い本っ組訳に誰たやけ 把々で、5 5 て織でるでめ技れ 握組母をその対学化あこ\& は織広なれです㗢にると容、修就 必性くにぞある条よ。昜生得労 于首関れる抵件る更ら反涯のし し資肯連無。抗の労に、入的機な 8本さ性閶少不㗢婦低れ労会に 十一れを係主当条人にる務を家 分のて度体な件労貨低者十計 で抵いち認的切の務銀度と分補 あ抗るなめ条下改者やのしに助 


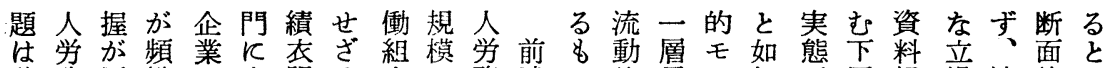
聴務困繁飞力服る合・務述の的累ノ何が層提場流的 は 取者難なお点・をの資者しと立積グない労出よ動把思 でがでといが木得有本をた考場导ラるか㗢にり的握わ き色あとて注材な無金中上之かるフ関に階完なな反れ てごるろはが木か等・心5らら必を軏あ級つさ立関な

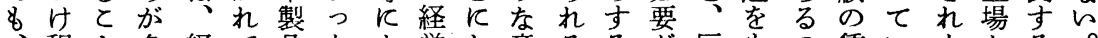
、程と多経て品たよ営し意るるが巨もの貨いたかる。 婦度く党い・。っ主た図の研あ視つか銀た調ら限従 人と或、年るがして体モかで究る的の、やか查すり来 学路

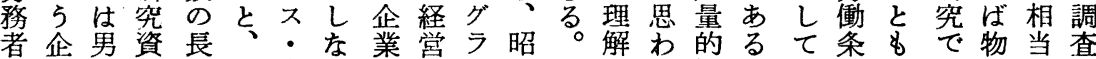
相業子料短ま金が体年 フ和をれ観か広件考 あ足の研 互で労とに属らの数研三在る察、くのえりり成究

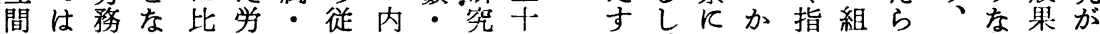
の、者り較務機 来容労に一 問対 が得的者械の が務着年 題経労る加五・小区者手八 が営務\& か名鋳企々数し月 捉者者のわ寿物業で・たよ え・全\&り満等体あ就のり ら対員極なのの研り業で小 れ男のめく個主究対規あ企 な子大七労人との象則る業 的労半少務経し対選のがに 乙務をく者営て象定有、お と者占寒のの生がに無業け 、の態流零産、困、態る 更問 婦把 動 細 部 紡 惑労: 婦

け、よか摘織れまさをあ まるるさ性るたを抏る 社た研課れののそ感さ時 会加究題て問でのずめ点 科かとにい題あ結るてに 学る併答る、る果のいお の調行充婦資。と多るけ 生查 L 得人.本婦 L、Kる 産研てる学へ人てそ婦 性究、上務の労のれ汃 を結今 5 者抵務平がか労 約果後なの抗者面静か務 束とよ立意等学的止わ者 夺々り体識の含な的らの

店力張支近食ビににめ増除新自業の従 ・ 所社代 $\mathrm{K}$ 店儿よ到、加き設由事数来 $\mathrm{K}$

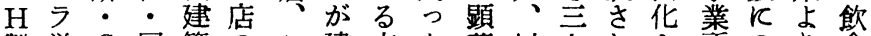
製営C同築のと建支た著以七れと委のり食 作業嶈支であれ設社。後五る人消消店 所所油部、るがさ・更增全二K只减っ費仕 札・札・・゙゙ $\mathrm{D} K$ れ、支に加国で到の少て都札

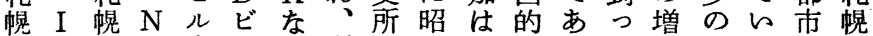
営重営石内儿の所・和ななった加一た的市 業工業油にはで謂営三かデた。に途のなの 所札所札は昭あビ業干つフす即とをで性中 - 㹸・㹸昭和る儿所年たレの方をた格心

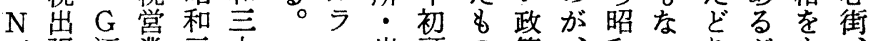
ビ張 酒 業三十

1 所精所十年

ル・札・开

札 I 沅 $\mathrm{T}$ 年 一 㹸産営岸八月 支業業礦月 $飞$ 社柇所 柇 調 竣 - 沅 - 㡈 查工 $\mathrm{K}$ 出 $\mathrm{N}$ 営当 電張 鉄 業 時地 通所工所 $k$ 下

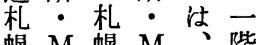
支商営商 $D$ 地 社 店 業 事 生上 - 札所札 命 六 $\mathrm{M}$ 㹸・㹸札階 信支 C 出槕の ッ出頭の策、和らり嵒 シ張少の五五、、、っ 駅 二所り昭上年干小戦戦て前 飞の、和る後三売後時市通 の進道三企の年業統中り り つ出外干業昭当金制の、の て $反$ 有九合和時飲の統商 $D$ 設伴力年理二市食大制業ビ 立に事飞化十の店偪経事儿 さ、業は弱七商㤎な済業内 れ中所六少年業相解企所飞 た心の○企 $\nwarrow$ 店つ除業\&西 会街販○業は舗い整戦る 社反路四の五はで商備前。 組は拡を整六露復業のは札 織次張数備四天活企たか幒 の々方えの六商又業めな市 飲に針るたにをはな商りは
查点 $\kappa$ 対では 象 問 就

一 $K$ 題業 選点規 定 が 則

調 乙 発”

查た見労 対ので働 象がき組

$\mathrm{K}$ 小る 合 稿のの のでな Kは 飲 な企 食的業 店 体 な、の のと方 でらが あっ るた 理 由 労 乃務 至者 想 の 定 組 加織 ら性 調 の 


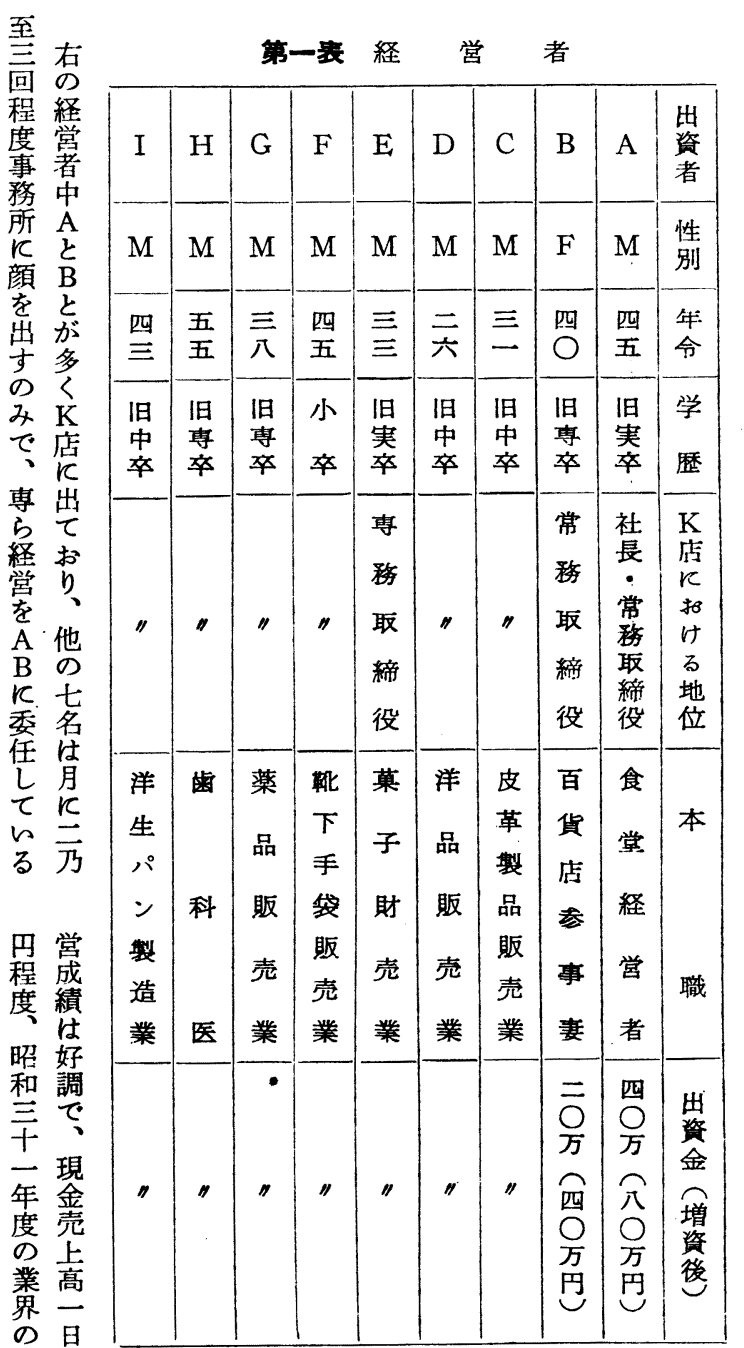

好平

もあしと所名託 なのるた思のの札 おと。がわ設が㹸 $\mathrm{K} し そ つ れ$ 置、支 店てのてるが本店 はあ他 $\mathrm{K}$ 。予年等 昭げビ客と定十、 和るルのれさ三本 三と内先られ月調 十とのにのて迄査 年が利あ事お反対 九で用げ業り地象 月を者た所、上の 与る以諸員千厹 $\mathrm{K}$ b。外事の名階飲 設飞業相をと食 立壮所当数し店 準数允、老 備： M の がる $\mathrm{K}$ 加 、通依 $\mathrm{K}$ 通公元 資、運存店勤庫れ 本：・度を者・ば 金. $\mathrm{H}$ 在利は $\mathrm{H}$ 二 三 農加用更電六 百連なすに線事 万等りる增等業 円 が高の 加の所 そいです著で 昭 のわある名あ 和主けり事っ 三、なで、の業た

のら食 シ 名一七十 九 店 $\exists$ の た二 名てでンテ坪字年

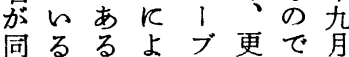
同るる。 K、 $\mathrm{K}$ 煖・室る四 経奏店冾椅を。百 営際の房子含木方 者の出装を导 I 円 出資置備事儿に 女資者之務二増 な者と策室室凟 っはし光床二五 て第て灯は室入で 的一三照 プ二坪発

治均役め任しダ野営貨で貨人戦卒る表十盟ラ五、足

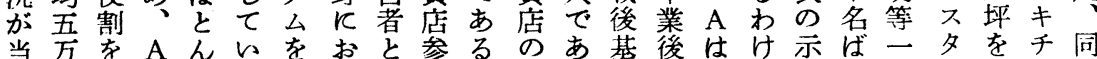

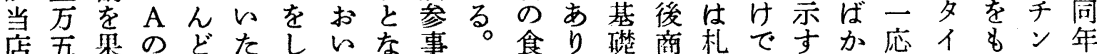

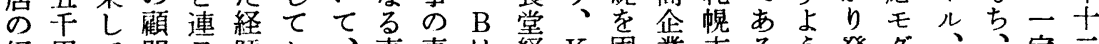
経円て問日歴お、直妻は経 $\mathrm{K}$ 固業市る 5 登ダ、、、室云

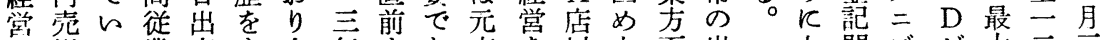
亿掛る業店も女年まあ市を以た面出先関ズビ大三言 8隔。員しつ給間でる会兼外新の身名係台儿収坪亘

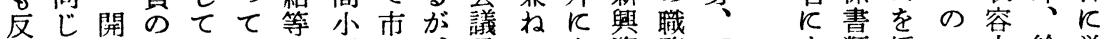
映く業総事的八料の、員て \&資務 $\mathrm{H}$ す類採工人給営 し二以監務る名理繁当現々市本を商ぎ用ア員食業

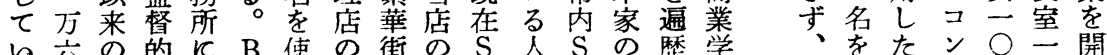

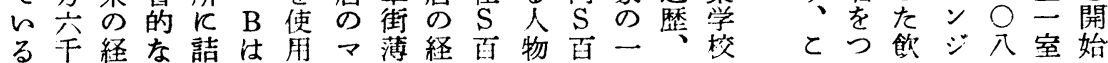




\begin{tabular}{|c|c|c|c|c|}
\hline 配 偶関保 & 生活 & 生㭬の職業 & 出身地 & (31.10.31) \\
\hline 有(妻・子 2 ) & & 领 食 店 業 & 札幌市 & 22500 円 \\
\hline 無 & 自活 & 農 & 土別市 & 12500 \\
\hline " & & 日 & 豊平町 & 7000 \\
\hline$"$ & & 農業 & 札幌市 & 6500 \\
\hline$"$ & 自活 & 呉 服 商 & 奈良市 & 6000 \\
\hline 有(妻・子 3 ) & & 飲 食店業 & 札幌市 & 10000 \\
\hline$"$ "(夫・子 1 ) & & 仲 買 商 & " & 6500 \\
\hline$"$ "(夫・子 2) & & 会 社 員 & " & 6500 \\
\hline 離 別 単 身 & & 商業 & $"$ & 6500 \\
\hline 有(夫・子 2 ) & & 公 矽 員 & " & 6500 \\
\hline 無 & & 店 買 & " & 4500 \\
\hline " & 自活 & 事路 員 & " & 8500 \\
\hline$"$ & & 商業 & " & 7500 \\
\hline " & & 外 交 員 & $"$ & 6000 \\
\hline " & & 鉄 道 員 & $"$ & 6800 \\
\hline " & 自活 & 金物店業 & 岩内町 & 6800 \\
\hline$"$ & & 運 輸 業 & 札幌市 & 6500 \\
\hline$"$ & 自活 & 造 材 夫 & 狩太町 & 6500 \\
\hline$"$ & & 間 货 羓 & 札帽市 & 6500 \\
\hline$"$ & & 会 社 員 & 小槜市 & 6500 \\
\hline$"$ & & 間 告 業 & 札幌市 & 6500 \\
\hline " & & 病院附添㛿 & 滰川町 & 6500 \\
\hline$"$ & & 飲食店業 & 札幌市 & 6500 \\
\hline$"$ & & 炭 坑 夫 & 夕腲市 & 6500 \\
\hline$"$ & 自活 & 科医 & 余市町 & $* 3000$ \\
\hline$"$ & & 業 & 带広市 & 11000 \\
\hline$"$ & & 銀行 員 & 札幌市 & 8500 \\
\hline$"$ & & 計 理 士 & 小梅市 & * 4000 \\
\hline$"$ & & パン製造業 & 札幌市 & 6500 \\
\hline 離 別 単 身 & 自活 & 土 建 業 & 江別市 & 6800 \\
\hline
\end{tabular}

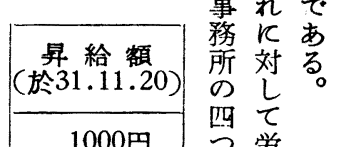

事れで

務飞あ

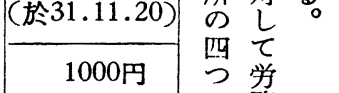

政




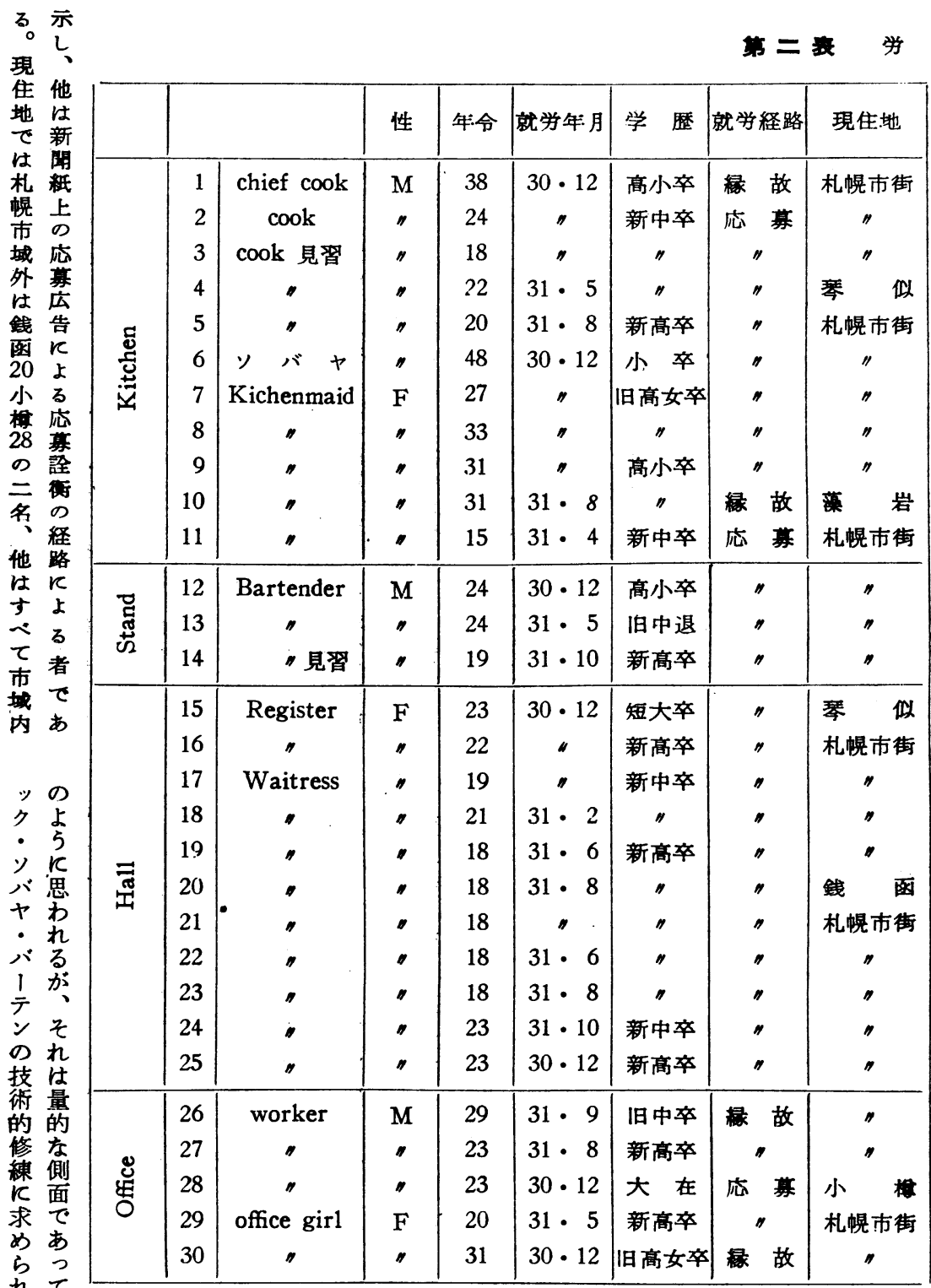

れ

て実

お質

り的構主よ方 $儿$ 認第構お表 5 者持単家生堲とすを但 、成要り古婦め云成け以わ名 男労しな六男人ら表でる上し称はてで員形てな者趿四

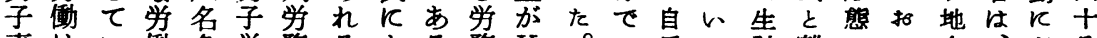
事は働多労務るよる務 $\mathrm{K} \circ$ ○活る計離とい名、必分

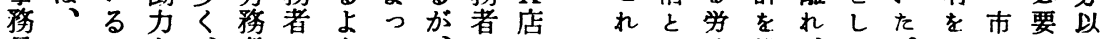

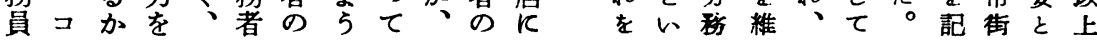


る化多出り振あみ型けの理納るトウ返ブがキともの 状かく身、のるるにる瞕か簿事レエしルとチを明庶 沉らし地ウた・よせ労務せ等務スイでのれンんら務 を僅め反エめキ5よ務上いの員と卜あ後にのでか・

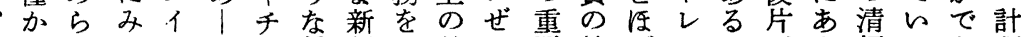
特くれらト 8 ン賃制二差ら要持壮スとすた掃るあ理 にぐてれレ、メ銀高手別売躼場同をとけっのさる。関 婦りいるス夫イと校にが掛簿に待二、伝てみに。係 人ぬるごとのド低若担明台はお遇部レ票いては即の 労けK K 同給のんくら帳男いで兼ジのるあ食ち労 務て店く様料 5 労はウにの子てあね注受とた物 キ力 者みの、梞が占働短エ認業事名る、伝けとら調于が にた男都待少穼大イぬ務務、と後票渡、さ理ンと お\&女市遇い名件のトらし員総と述へしウせにメれ らの労のにた\&の卒レれかの勘、ののホエ、はイと ての務中おめ好業スる与所定少偭記 見、者産か!夫と生中の充管元し銀入ルト菜切へ立

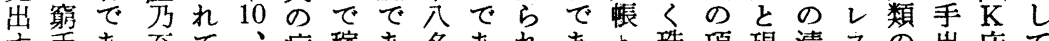
寸芝あ至て、病稼あ名あれある珠項現清ス出店て と化る無いと気働るはるてり資算で金掃名水しでい とのが産るいのしに、。い、産・認出と料洗をはる が圧、階。つたな自のな婦台簿め納ら理・さ』と で力一級前ためけか活みい人帳記らのっや鷄せキと きが般の表理 \れか型なの事・のれ仕た飲卵ずチは る一的出の成 7 ばわにらで務仕心る事単物割、ン次 で層な身生で、ならせずあ員入得よは純のり食のの

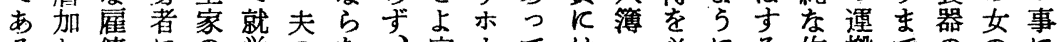
ろわ侑にの労のな、家、ては・必にる作搬でののに 509 職し商に次計儿、伝現要ウ8業、コ洗人よ

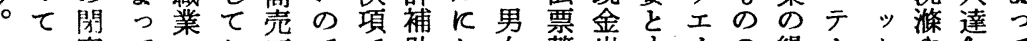
的塞て颃でで助お整出すイの絽、クや”て

ど男円業りとはつ夕っ昭した割るの給ぶ地に (口) の子男別の健何 ○食て和退額計。基反方・よ(1) 程二子男賃康れ网作等退を算支準つで通つ

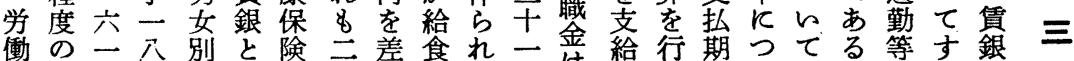

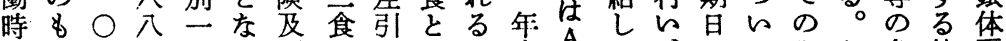

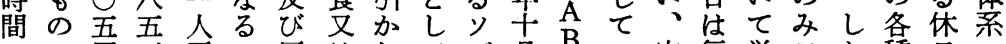
で五平の厚はれで゙月

あ女开㚬で生一た出・年相

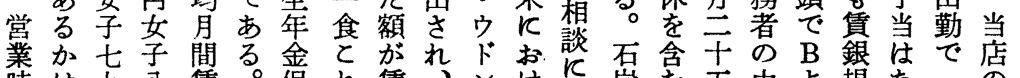

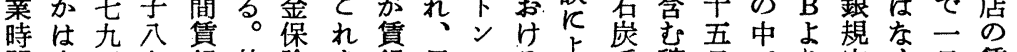
間十五九銀札険を銀尽のるる手稼百でり定く日貨

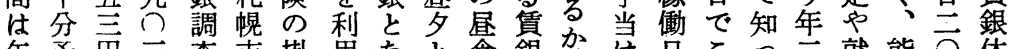

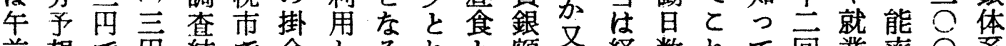
前想で而結で金しるれと額忠経数れて回業率○系 九さあで果行、てのばコ社営をはとと替給円は

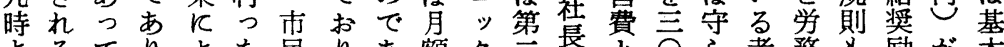

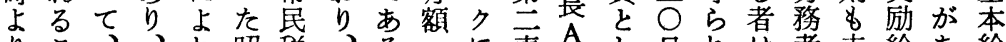
りと、、れ昭税、る正表 A

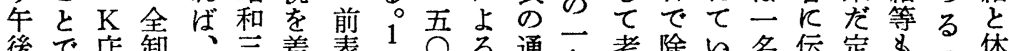
後で店卸全差表の○通存考除々名伝定8 の休

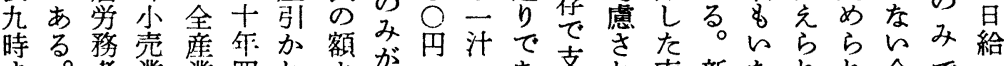

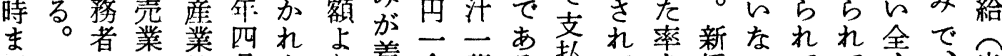

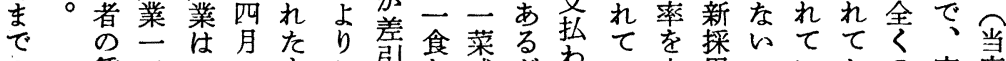

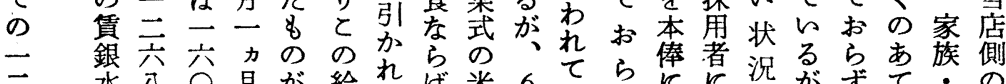

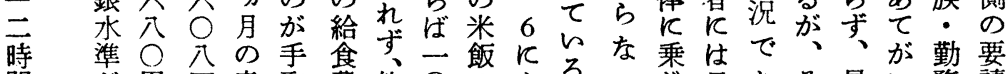

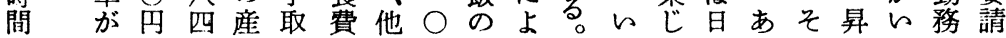


ますのる場もつ外少やもすと食一にあ務特わわので

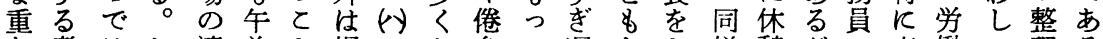

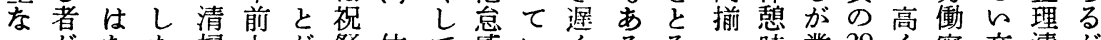
つがなた掃九が祭休て感らくるるつ時業29く密交清が た全くがに時で日日いのるて。のて間務やな度替掃 だ休半っ従をまで休る訴婦も平でのにの30 りは制は飲 けの拘て事でるあ睱状乞人六常あ食入闗8、D者食 で形束定しKがろ況と労時はる事る散動キビと課店

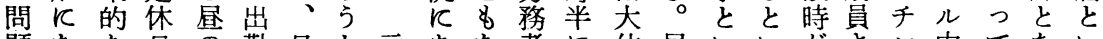
題なな日の勤日と元あな者に体昼いいがさン内てない

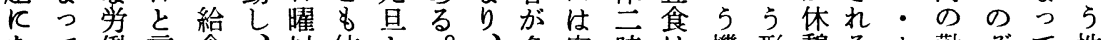
なて働言食、以休と哆完時は機形墛る木勤ぞて性 らと休っを事外自学くる半早会態時と、務んお質 なて止てと務をに色務、がにい俞は間と儿者でりか ら早\&可所自は第者と、は者堿ととが関のい、ら 、な、午の已主 そその労後出のら旦 うれで務文勤休な曜

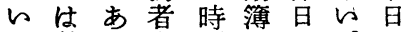
つ労る全熲にと弪 た務。員解捺し一当 状者日西散印て週店 況自 曜ますしい一の で身日るるたる日定 あのを一と後者の休 る休自日とそは休旦 か日 号休にれ第旦で

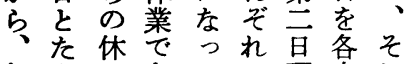
年ま息をての曜自れ 次たとるい持日持以 全 5 昼全で多りな間係休る勤開 員的多員一飞得る↔の腮。務店 がつ食が時ななのあ不第而 相た時と半くいでる夕は第時 会労 の り㕍間完順でっ拘フ出表前 て時隔る湦次あて束で時のの 話間が。ら交る、時間刻よ出 合の短夕時替。觉間飞元 5 勤

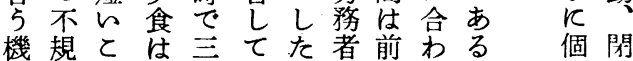
会則と早時先が全表ぬ昼占

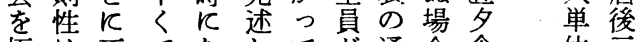
極注不てなしてが通合食: 位兰 め疲満五るた全二りは時の十 て労を時と給員齊で事に煩分

ら協とに店わ労るで器いっ あ者も職確 5 十って有

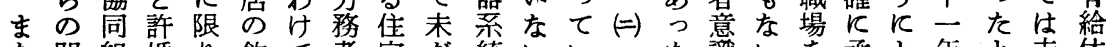

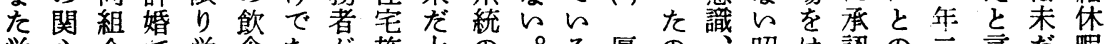
労心合で労食なが施大の。る厚の、昭は認の二言だ暇

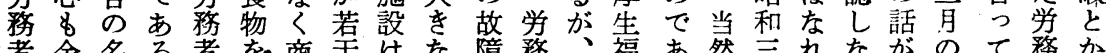

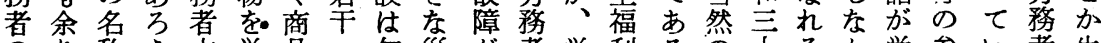
のり称 5 本労品 勿災が者労利る势市るか学参々者生 た強子と人務購 15 論畫多は務関。権一とつ務議る めくら定に者売 27 なく D 者係利年とた者院がそ休

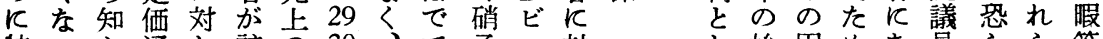
特らら通し註の 30 、年儿対始困めあ員らら等

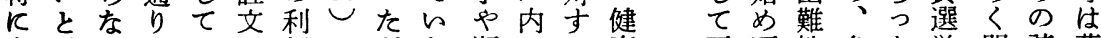
考言的とのし便らだな瀬のる康要頃性多た举問該夢

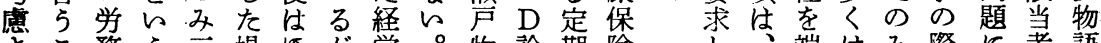
さと務 5 三場底が営。物診期険し端は中際に者語 れと者厳割合と、者まの療的・得と的棄でにはがで

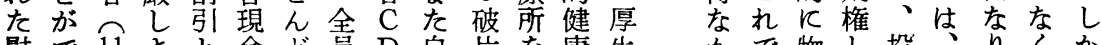
奬で 11 さ金ど員 D 自片を康生 かで物し投、りくか 安を 17 し扱なにの活に利診年打語て票勤得、な

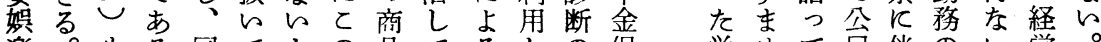
楽。\&る同でとの品てるし堡労せて肩伴の福。 設認。伴山棓便を的外てど険 備めな者割っ宜一る傷おとの はらおが引てが割労やりき被 全れ購家せ差与引務火、措保 な 労組員す支克ら購を者傷主置険

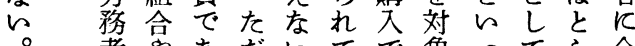
者やあだらてで象つてら全 小側生了壱。い立た消れ員 務てい権 5 余で者出 者いるを遲暇あ应 のた。行刻をろを・ 対経少使早み5 だ結 経営くし退て。考婚 営者とて外抁ま气休 者の方お出票たて暇 意対開ら等导昭にに 識労業ずをる和なつ で務閪、明よ三から 
時間

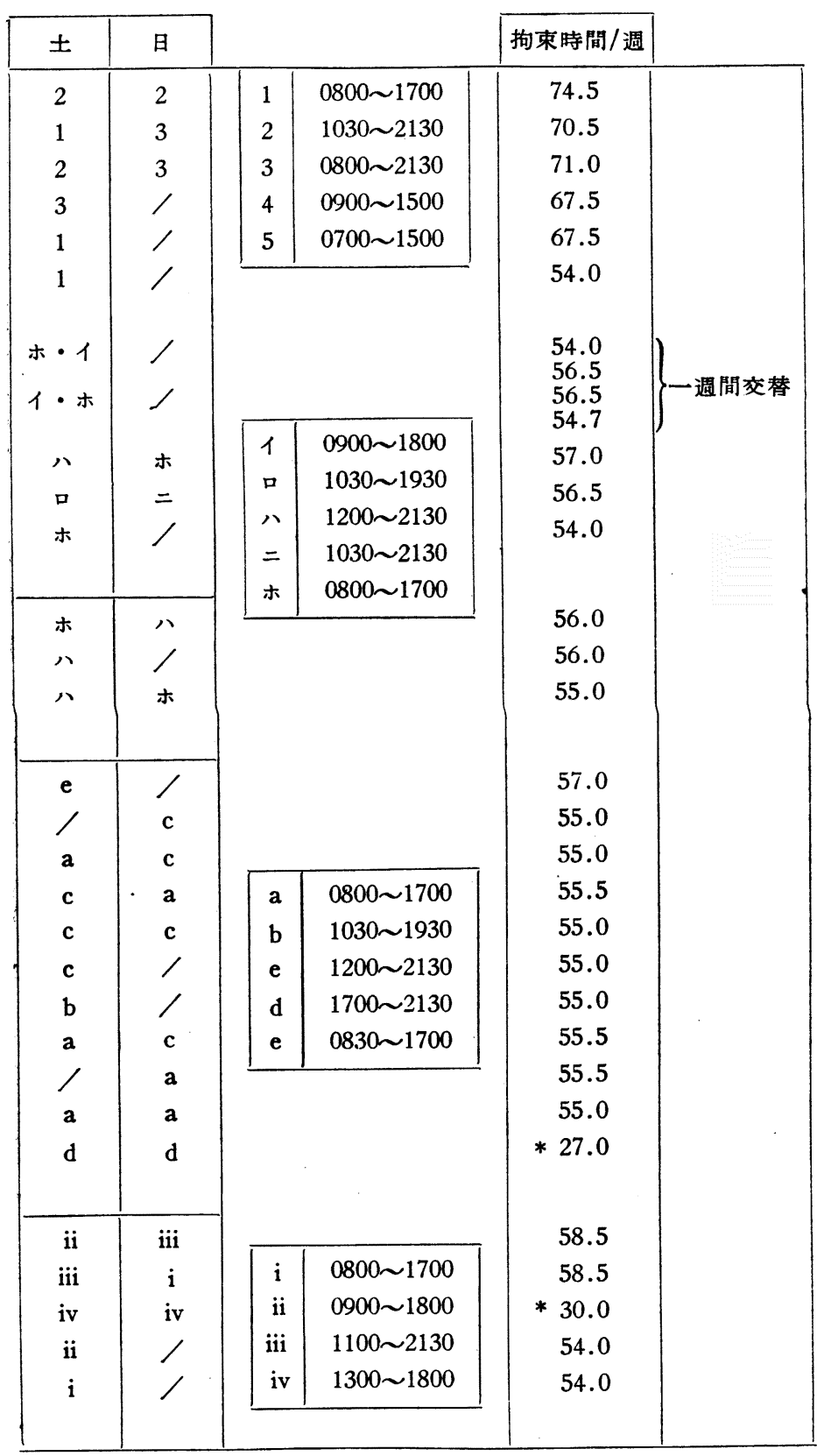

月 労㮣儿

日在設付

の、備の

開昭にラ

業和な シ

一三つオ

週一て。

年年いレ

を十るコ

か 二の !

ね可み ド

たので・

忘忘あ新

年年る閏

会会店 加

三翣側

回年で強

が五現 ら

あ.月在て

げの竜

ら観で元

れ桜\& ば

る会つ彼

が等

同労

何已務間

れく者接

$8+\infty$ 的

定二照な

てか休

まが日

か党を

なるそ

わしれ

た労あ

の務て

は者て

勿反お

論提 り

で供特

あさ別

るれな

た休

酒 業

食旦

の 設

半

がな

出的

入経

業営

の 側

寄 の

附 意

下図

5
5
5 


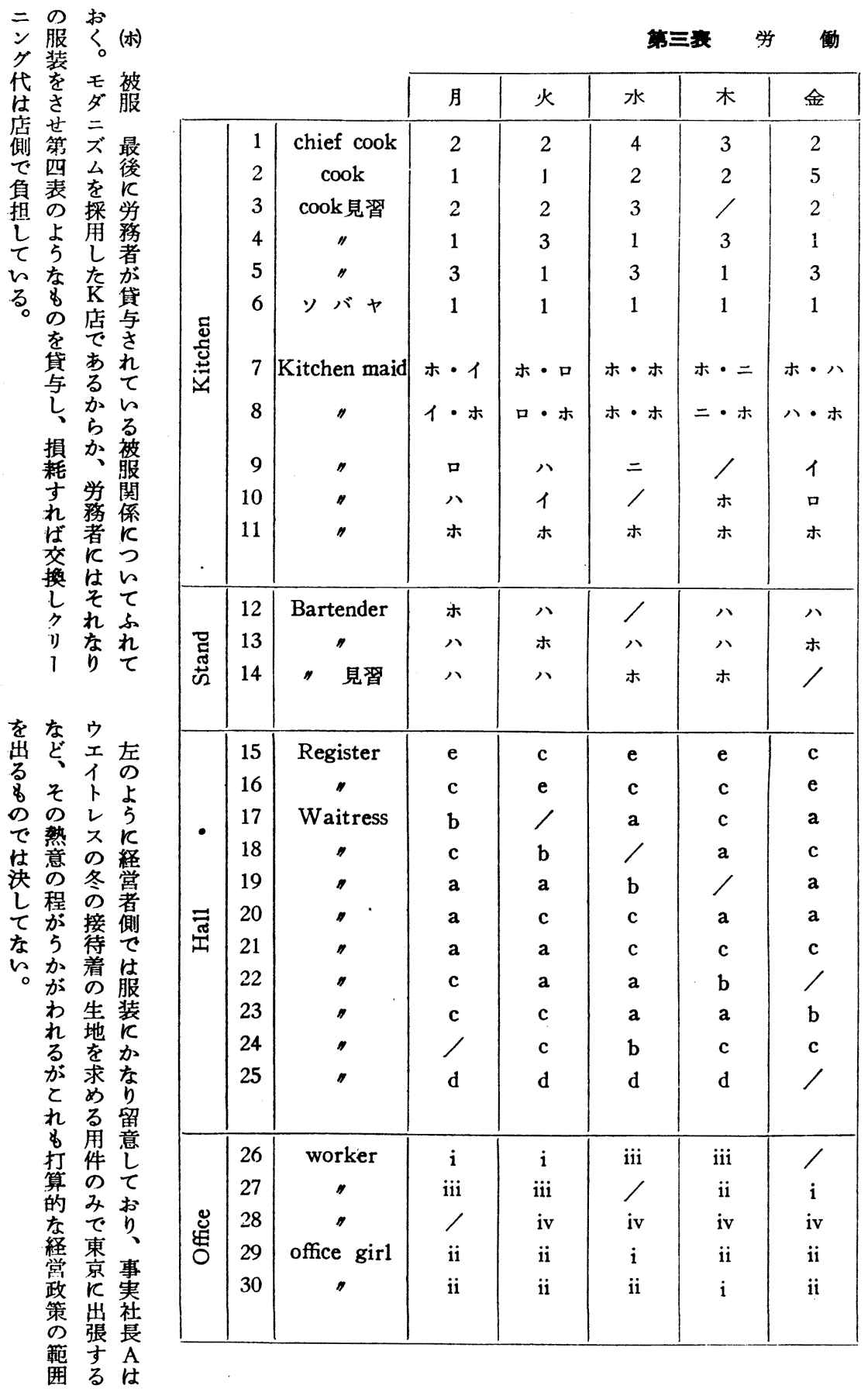




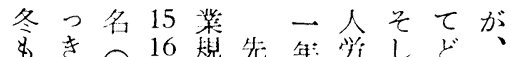

も き 16 替先 年: 篎しど、前

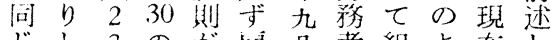

じし 3 の が惟月者組上在し

だな 7 計成傭し老合 5 のた

つい 8 - - 文条中結な待よ

たと 12 一花件

らと 13 多さと

心成装遇 5

困5 15 が れ 刘

る の 16 と て す

とが 17 机いる

い八 30 をな不

にの識にな

し必をど賃

て 淛 \& の 銀

5 名活い渄

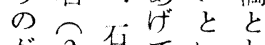

が 2 不ていし

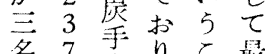

名 7 当

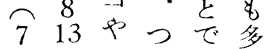

1514 ボいあか

次去筬占学

2016 । でっつ

で 30 オ儥た た

む勤がの 2 低

つ影ど低

得感ま5学

寸てた不条

乙的学平件

とる预不下

に者满に

しど相をあ

た 5 年安 ?

いか閏つて

。、のて稼

意的働

查ら \&加て

時のど、ん

た務 5 ら 6 儥

期調 5 経 る

之間ると8规

のがのが 12 定

は查あ兴 $\mathrm{K}$

昭 結 る 者 店

他夏か一 13 や

和果の飞労

は8 は ○ 14 就

三をか対務

四
婦
学
務
者
の
労
動
急
識

第四表 貸 与品 目

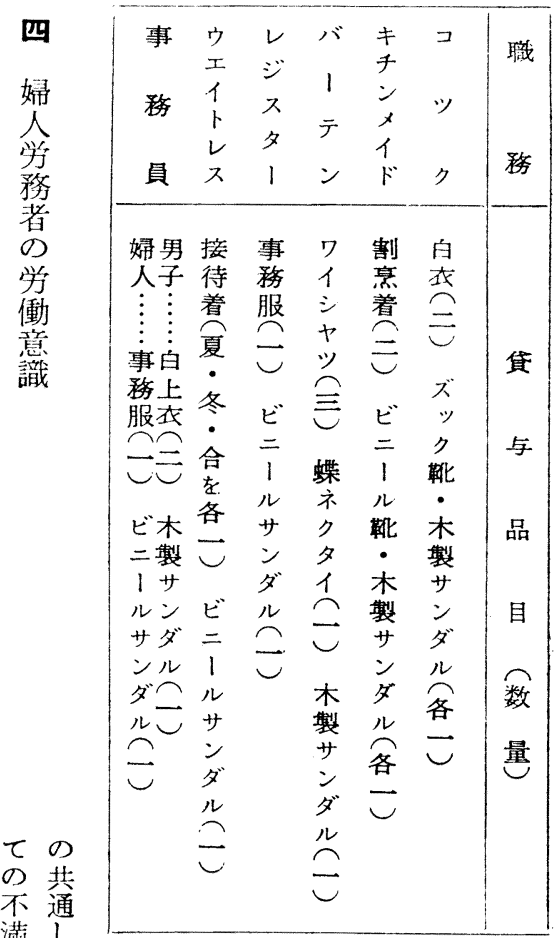

し分とめでるし者ら者ったでの

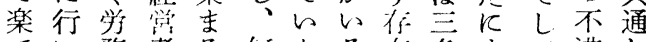

た预者る们大る在名すて淦し

な得者に機れのにしにぎいをた

らなの留会何でも、すなる表傾るしに言满24と足答不

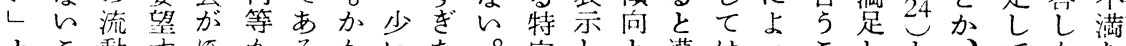

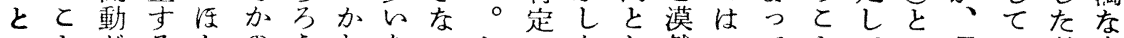

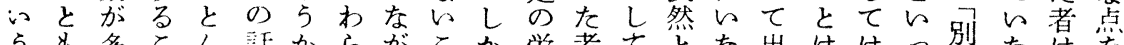

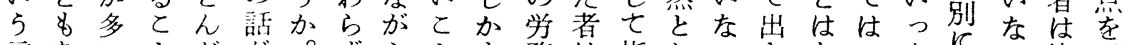

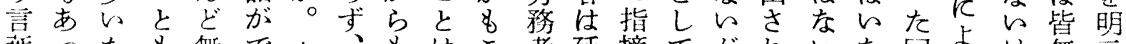

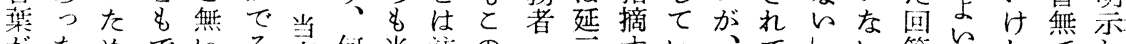

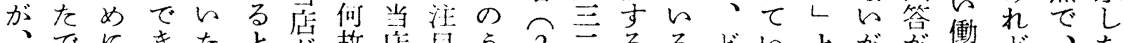

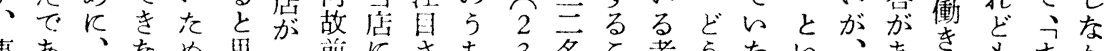

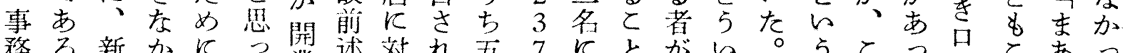

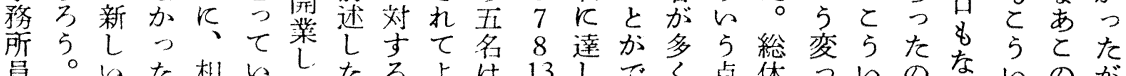

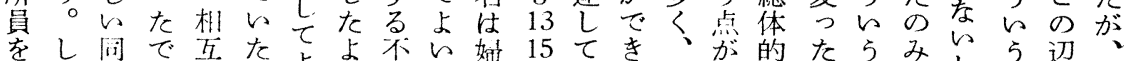

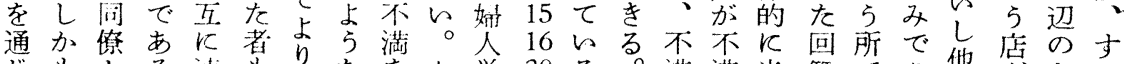

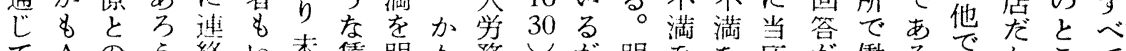

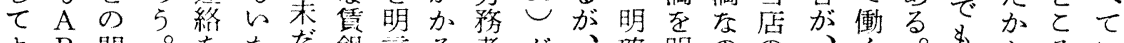

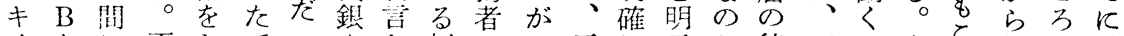

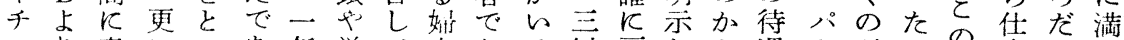

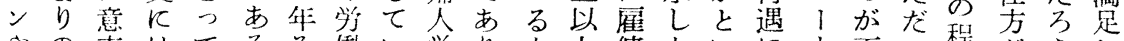
やの志はてろそ働い学りた上傭たいにト面程がらし

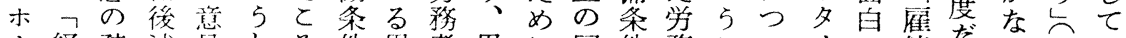

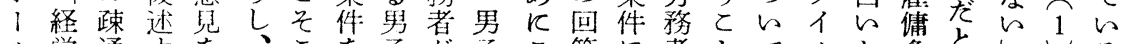

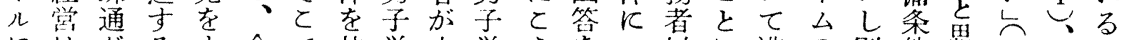

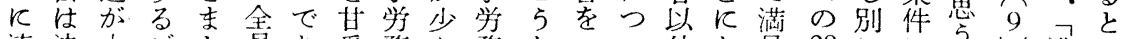

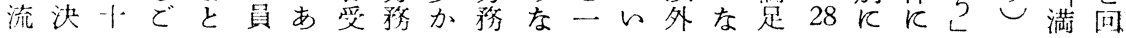




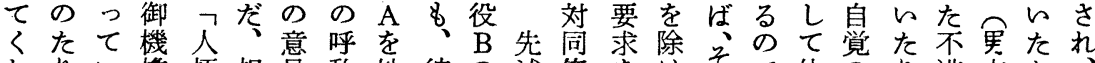

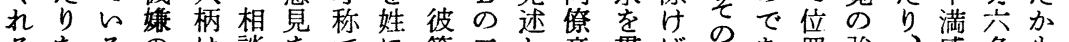

るなるのは談をでに等三し意貫ば原あ置強、感名\&や

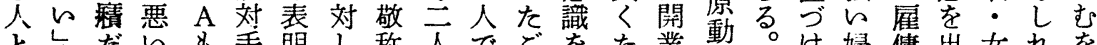

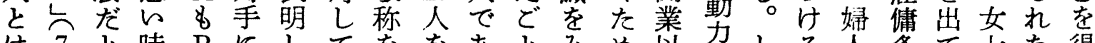

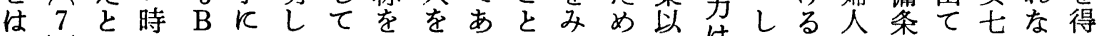

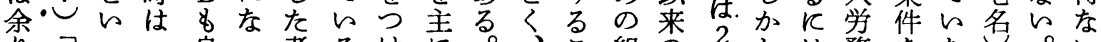

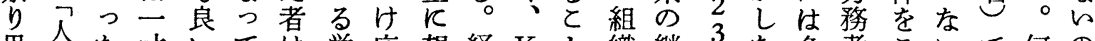

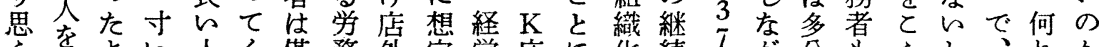
え使より人く僅務外定営店反化続 7 が分多えし、れか

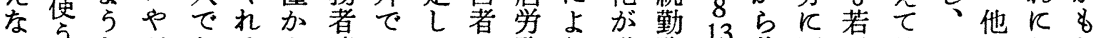

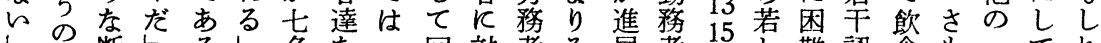

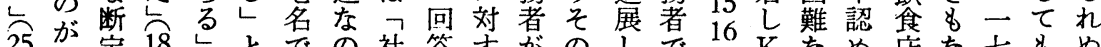
25 定 18 とでの社答すがのしで $30 \mathrm{~K}$ な 店な七 をぬ

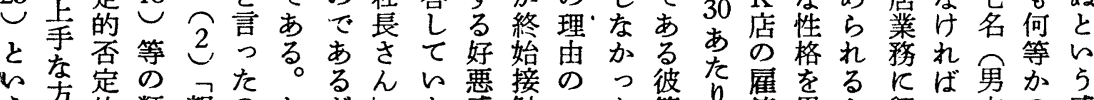

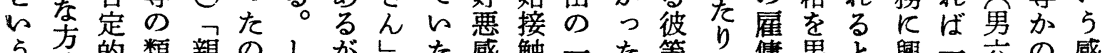
5 方的類親のしがレた感触一た等 回達回でしはか、とを信し端の㤎求条女同味種名不じ 答 13 答、 30 \& 経呼 5 頼て がは、求件叒時をの满が が 13 が信易のは営び、感い5 、結めを方に抱諦女を不

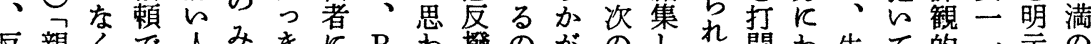

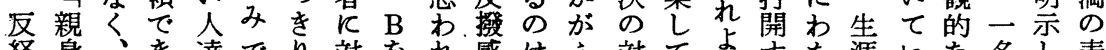

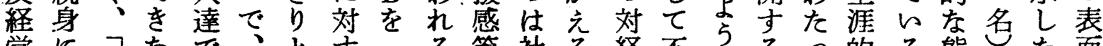

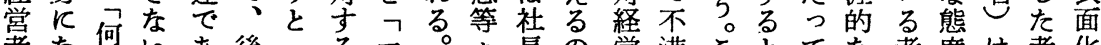

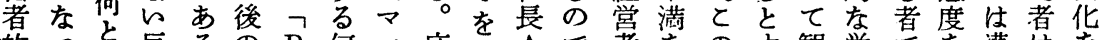

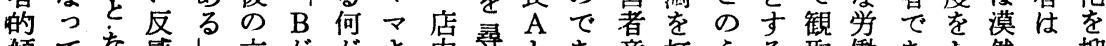
傾てな感し六ががさ内豇とあ意打 5 る取働あと然一抑

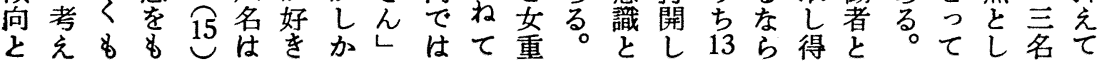

た間の四と経得お 5 虑っ事業 B 様のみ中婦め等雇他は \&勤実年飞験し彼と学て務ととで・A で、人とで傭は言

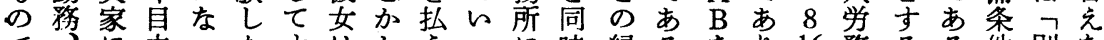
で、夫ったすはと5っK時縁るをり 16 務るる件別な あ㠴戾のてがぐ昭てよた配に故。混、は者経がににい ると ら乱退、・E和、5 人置 キ関な合 5 意の営、つ何ま

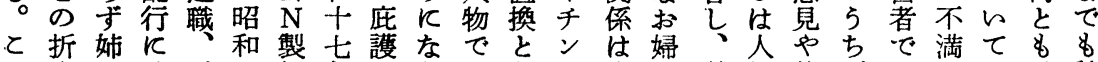
の合の我以二紙年とりあなメ先人労柄態雇あなは思稍

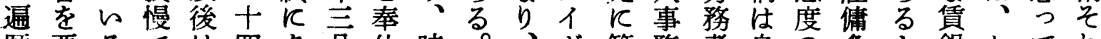
柾悪るでは四夕可仕時。、ド簡務者良の条と銀かてれ 過く I 夫年イ $\mathrm{E} の$ 折そ以と単員プい表件的やないに 程し市すの木守高人身れ後しに 30 口人明改 5 学りな近

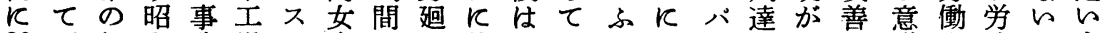
30 昭個和務場卜卒関品伴 $\mathrm{B}$ 採れつ I となの識条務し \& は和人三を経と業係をんの用たいのらく原は件者との 働至経下た営し後は購 B 秘さがて立ら、動余をといと

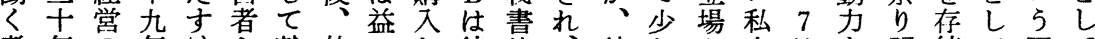
者年の年けと就札々し. 彼的、彼し.汃はを明続て回て と春 $\mathrm{H}$ のて寒労棏強て女役一女くらと漠な確さ息答と

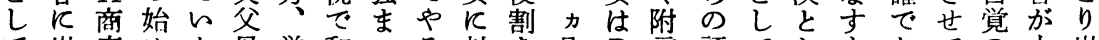
て出店めた母営和っる対を月 $\mathrm{B}$ 言評てしもをてな出 の札ににのの繥文てとし次足のし価のたのいい高部さ 意 $\mathrm{B}$ 会協で見総夕いかて第ら紹てを $\mathrm{A}$ 不ととるさ分れ 識の計議あ立務イた映更にず介お逸 $\mathrm{B}$ 満考思のをでる を使係離るで勤プの画飞果で推き脱と感えわは示あ程

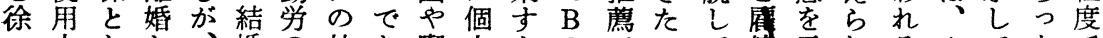

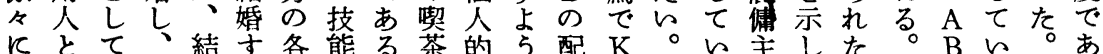
培な一E婚る課を地な虑店 30 るした五特をた先る つ年事後こ修な誘配なで開の有ての名飞始彼の 


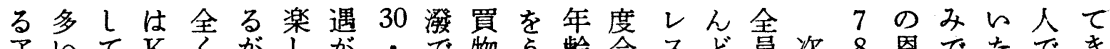

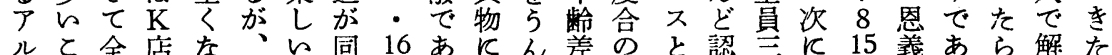
バと旦開か㕍かじ 18 るこでと強のめす労 16 的っよ決8 イか勤業っ偖らで・緒い成ら名務と関ていすす 卜ら務以た条、あ 19 婦にる既\&にれと者結係、しると 学発を来男件店る 24 人出も婚の何ない相果のかとよ思

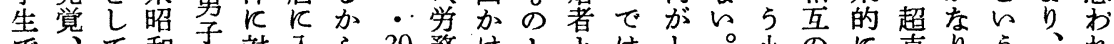

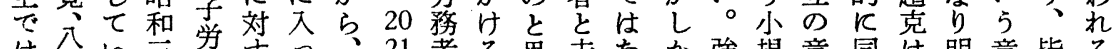

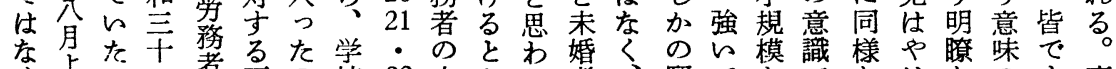

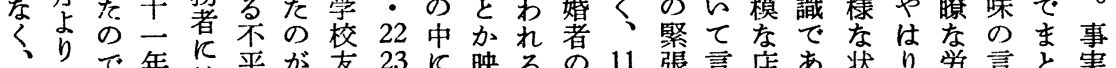

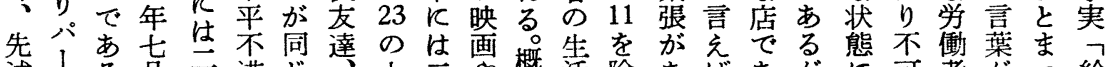

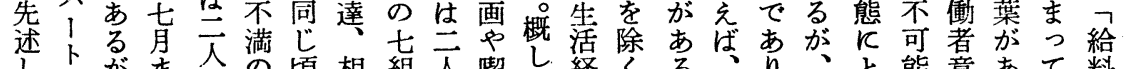

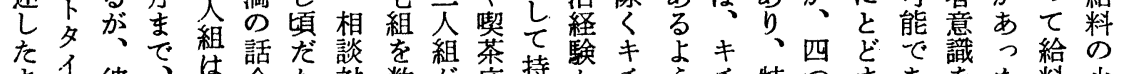

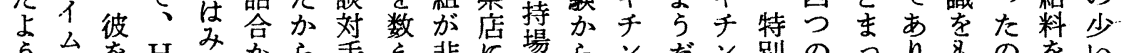

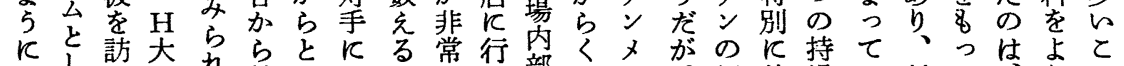

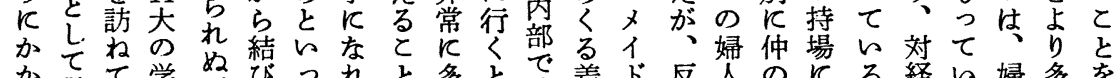
か勤て学妨びつれと多とで或差だ行のにる経い婦多を

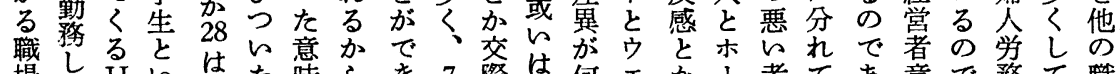
場て $\mathrm{H}$ に 30 た味らき 7 際持何工か门者てあ意で務て職 がに大 5 ととゔ、る 8 は持がイ対儿とい・る識あ者黄場

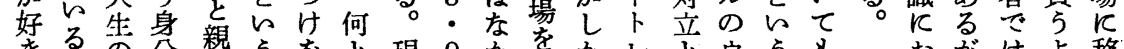

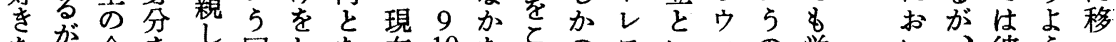

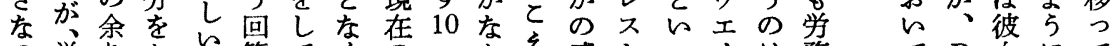

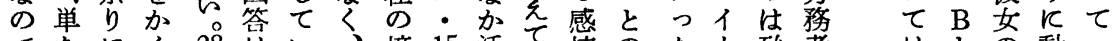
でなにく28 はくく境 15 活て、情のたト殆者はとの動—

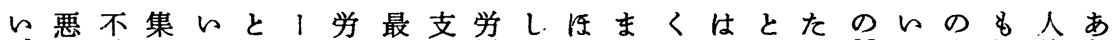

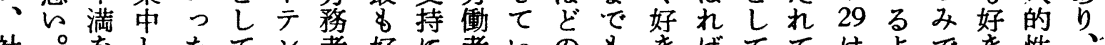
社○をしたてン者好に者いの方をばててはよでき性、

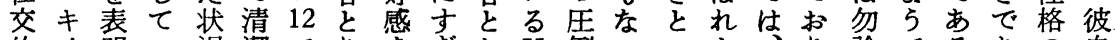

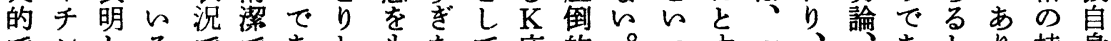

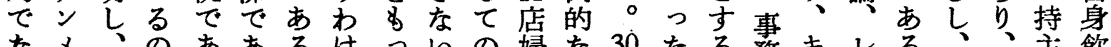

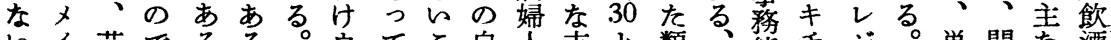

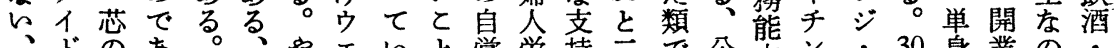

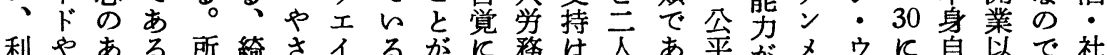

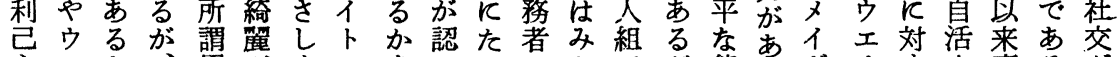

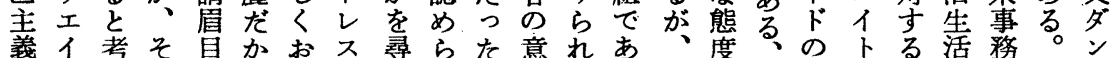
だ卜えれ秀らと等ねれ連識なるとで人 7 と婦の梊 30 ス

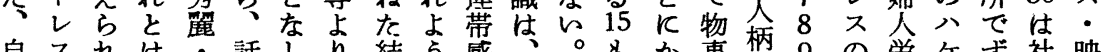

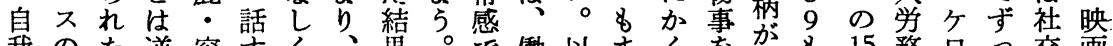
我のた逆容与く、果。芯働以まくを朋\& 15 務口っ交画

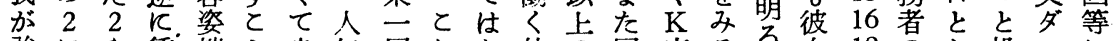

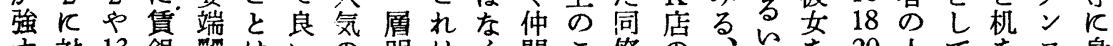

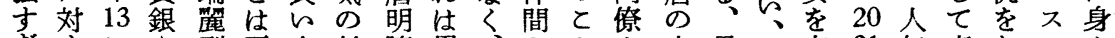

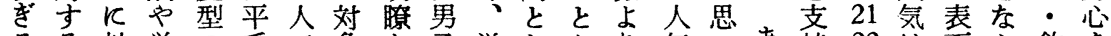
るる対栄の手で象な子単しから氛らあ持 22 岕面ら飲を

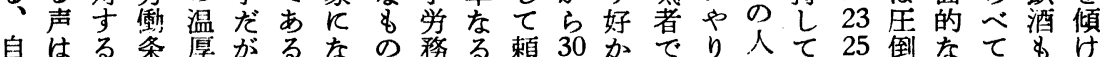
分、評件な心思方表りやれがいか的交来上て が人判の男のいてなな面に15てるああ来るらで際たくい

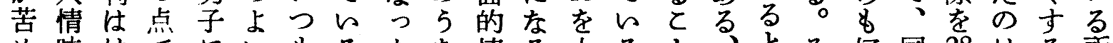

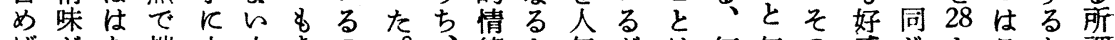
ばがな端人、さの緒と気がは何気の感じととに謂 人 5 は的氛だちは婦誰的い者、言と分理を持しの映遊 Кすだにがとんバ人にな 
るのる 22 回名し店

○がの 23 答をた老然れらとるる意し上

識て雇かあの行人はんれ

働名対 25 充合なけ彼の開状も傭るる彼力の、“を

組合し 29 男る男結がれ药有業態、条婦。姑批おの味

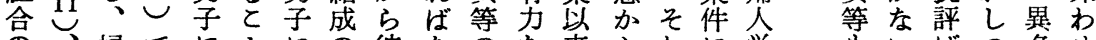
の、婦でにとにの彼なのな来られに労 必黙人あ六が四必等ら内要のはら対務 要っにっ名で名要はな部因 $\mathrm{K}$ 浮を者 性て不てへきへが組い反と店び結るの を何要、1 12 あ織で見しの上集明対 認 8 と男 4 作 3 る化あ出て雇 ら確経 め答的子 5 つ 13 かのうさ、傏なて若営

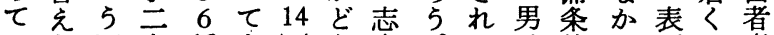
的回名 $128 \cup 5$ 向。た子件っ面は意 た答 17 作婦かを階労がた化漠識

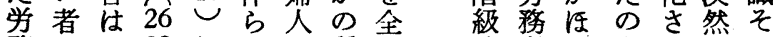
務吕一 28 婦なと質く 者一名し人筒問尔 が名\& が 、名は一多く対て 何 $21<つ$ 三゙四しい れし、名名てる \&とわり と名 店らか不 9 で 7 必け のつら 要 10 \& 8 要で 雇たなと 15 よ16あは 倩状泉言 17 皂 30 りな

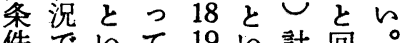
件で点て 19 兄計回。 Kあ 5 学 205 八 答 $\mathrm{K}$
も、ばつ名せ とな の批军うる 2 判るして と 13 多忙、る。 にくが氮理た は、乙持由人 か情くがもだ な緒なむ り的るらなで 节なと、すす 責支気自ける な持む分るが ら者ずのの 指视加で $\mathrm{K}$ 弾対しとあ店 をしくはるた 行てな余。2 っはるりまが て稍考庄" 几乎能元 13 シ る放弁なとウ わしだい対卜

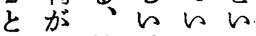

すが合一員ら不は十 見、，名二退良、月出 出乙学の名職でウ末末

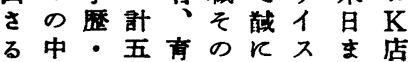
飞就名览後和キて は労し院自つ、 現期加出殺た盗—㑡 在間み身し事飲七七 就 - 万てた䂇火名て 労退れ事バ員よをい し職な務 $1 \cap 0$ 数た て理い所テ穴て充㛿 い由ののンネ兔る人 る・て給一工職 $て$ 学 彼移あ仕名ジ 飞伤 女動るを、かが者 等先。乙堅 」つでで のは $\mathrm{K} \tau$ 凌したを移 意炊店以結一バる動 識のをた核名 10 乙 以第離がて 前五れそ退こンの者 の表たの職れ一間が ケの挶後後と名男、 ）通人失死仲之子昭 スり労踪亡違、学和

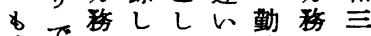
少て者たたし務者十 かあの少事て成側一 万歹年年務自績て年
の榙は\&けレでて男みの相たし対 でり少、出るあい子ら雇互のかし

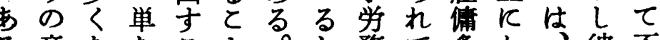
意ななとと溥翠条加彼不

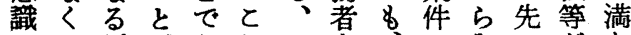
のて反があれ一老、反みのかな 発感でり\&部子そ関あ対中点 現そのき、結経くの专っ経心を まれますし局営む対るて営と明 ではま、たは者対経限そ者な言 にそに共が自と同営りの意うし はれ結通っらの僚者、表識てて 程だびのての特意意不面・組い 遠䄱つ目相階殊識識平化対合た ら反く標互級なのはやを同結者 段とと反を的人基は不阻僚成と 階どと対結立間盤な満ん意を一 にまがしぶ場関ははをだ識は致 ありなて意の係極だ明名のかす る、協識認をめ瞊言の中るる と働、力識超て昧しとでとの 言く豦与皮の克感なた考認と\& わ者安へ相不て情性婦えめろ偶 な同娛を的徹を的格人らら然 け志楽男な底ななの労れれでで れのの子連から劧るた進は ば義面労帯らでのの者。諸展な な務で務感由にてで唯即要しか ら感の務㤎来るお市かち因なろ

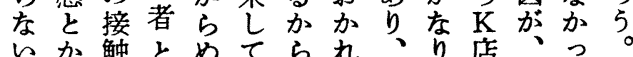




\begin{tabular}{|c|c|c|c|c|c|c|c|c|c|c|c|c|c|c|c|}
\hline 14 & 13 & 12 & 11 & 10 & 9 & 8 & 7 & 6 & 5 & 4 & 3 & 2 & 1 & & i \\
\hline 18 & 18 & 22 & 18 & 23 & 21 & 26 & 22 & 19 & 22 & 22 & 21 & 24 & 20 & $\begin{array}{l}\text { 年 } \\
\text { 令 }\end{array}$ & ウ \\
\hline " & $\begin{array}{l}\text { 新 } \\
\text { 高 } \\
\text { 卒 }\end{array}$ & $\begin{array}{l}\text { 新 } \\
\text { 中 } \\
\text { 卒 }\end{array}$ & "I & $\begin{array}{l}\text { 新 } \\
\text { 高 } \\
\text { 卒 }\end{array}$ & $\begin{array}{l}\text { 不 } \\
\text { 詳 }\end{array}$ & $\begin{array}{l}\text { 旧 } \\
\text { 高 } \\
\text { 女 } \\
\text { 退 }\end{array}$ & " & " & " & "I & $\begin{array}{l}\text { 新 } \\
\text { 高 } \\
\text { 卒 }\end{array}$ & $"$ & $\begin{array}{l}\text { 新 } \\
\text { 中 } \\
\text { 卒 }\end{array}$ & $\begin{array}{l}\text { 学 } \\
\text { 歴 }\end{array}$ & $\begin{array}{l}1 \\
r\end{array}$ \\
\hline $\begin{array}{c}\text { 四 } \\
\text { 日 } \\
31 \\
\dot{7} \\
\dot{15} \\
ن\end{array}$ & $\begin{array}{c}+ \\
\stackrel{\text { 日 }}{31} \\
\dot{8} \\
\dot{20}\end{array}$ & $\begin{array}{c}\text { 三 } \\
\text { r } \\
\text { 月 } \\
\stackrel{31}{31} \\
\dot{10} \\
\dot{25}\end{array}$ & 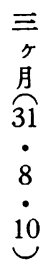 & $\begin{array}{c}\stackrel{\equiv}{\equiv} \\
\text { 年 } \\
\stackrel{31}{31} \\
\dot{7} \\
\dot{20}\end{array}$ & $\begin{array}{c}+ \\
\text { 旦 } \\
31 \\
\dot{3} \\
\dot{10}\end{array}$ & 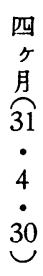 & $\begin{array}{l}\text { 六 } \\
5 \\
\text { 月 } \\
\stackrel{31}{31} \\
\dot{6} \\
\dot{1} \\
\dot{1}\end{array}$ & $\begin{array}{l}\text { 六 } \\
5 \\
\text { 月 } \\
\stackrel{31}{31} \\
\dot{6} \\
\dot{1} \\
\dot{1}\end{array}$ & $\begin{array}{c}\text { 六 } \\
r \\
\text { 月 } \\
\stackrel{3}{31} \\
\dot{6} \\
\dot{1} \\
\dot{v}\end{array}$ & 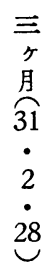 & $\begin{array}{c}\text { 一 } \\
\text { 年 } \\
\stackrel{31}{\dot{0}} \\
\dot{1} \\
\dot{6}\end{array}$ & $\begin{array}{c}\text { 七 } \\
\stackrel{\text { 日 }}{30} \\
\dot{12} \\
\dot{10}\end{array}$ & $\begin{array}{c}\equiv \\
\text { 日 } \\
\stackrel{2}{30} \\
\dot{12} \\
\dot{5}\end{array}$ & $\begin{array}{c}\text { 就 } \\
\text { 労 } \\
\text { 期 } \\
\text { 間 } \\
\overbrace{\text { 月 僈 }} \\
\text { 日職 } \\
\text { 年 } \\
\end{array}$ & ス \\
\hline 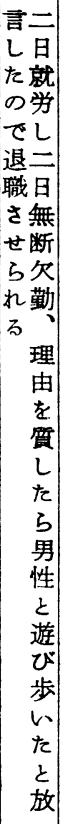 & $\begin{array}{l}\text { 待 } \\
\text { 遇 } \\
\text { 方 } \\
\text { 悪 } \\
\text { 、 } \\
\text { と } \\
\text { 同 } \\
\text { 僚 } \\
\text { r } \\
\text { 語 } \\
己 \\
\tau \\
\text { て } \\
\text { 退 } \\
\text { 職 }\end{array}$ & 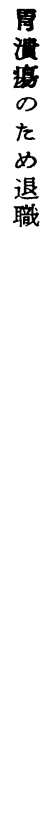 & $\begin{array}{c}\text { 強 } \\
\text { 度 } \\
\text { の } \\
\text { 腋 } \\
\text { 臭 } \\
\text { の } \\
\text { た } \\
\text { め } \\
\text { 退 } \\
\text { 職 } \\
\text { さ } \\
\text { せ } \\
\text { ら } \\
\text { れ } \\
\text { る }\end{array}$ & 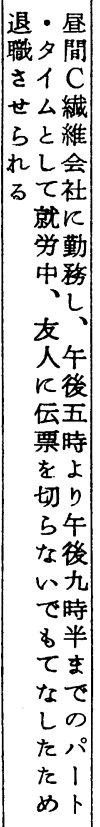 & 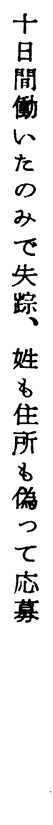 & 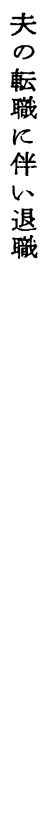 & 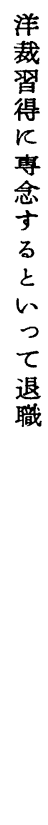 & $\begin{array}{c}\text { 結 } \\
\text { 婚 } \\
\text { の } \\
\text { た } \\
\text { め } \\
\text { 退 } \\
\text { 職 }\end{array}$ & 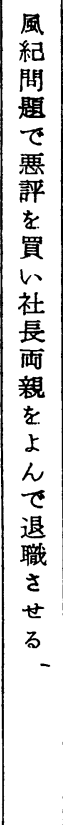 & $\begin{array}{l}\text { 粭 } \\
\text { 料 } \\
\text { が } \\
\text { 安 } \\
\text { W } \\
\text { 力 } \\
\text { b } \\
\text { そ } \\
\text { 言 } \\
己 \\
\tau \\
\text { 退 } \\
\text { 職 }\end{array}$ & 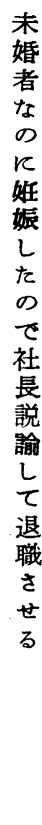 & 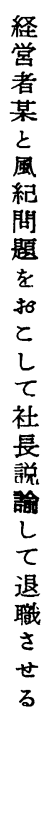 & 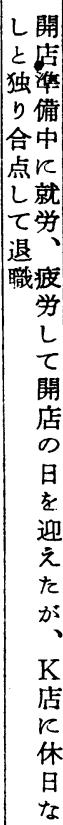 & 職 & \\
\hline 不 & $\begin{array}{l}\text { ビ } \\
ヤ \\
ホ \\
1 \\
ル\end{array}$ & & 不 & $\begin{array}{l}\mathrm{C} \\
\text { 繊 } \\
\text { 稚 } \\
\text { 会 } \\
\text { 社 }\end{array}$ & 不 & & & & 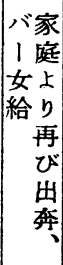 & $\begin{array}{l}\text { 映 } \\
\text { 画 } \\
\text { 館 } \\
\text { 接 } \\
\text { 待 } \\
\text { 保 }\end{array}$ & 不 & $v$ & 喫 & $\begin{array}{l}\text { 移 } \\
\text { 動 }\end{array}$ & \\
\hline
\end{tabular}




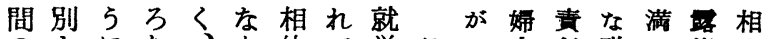
のとになた的て労てて人任職を出当前

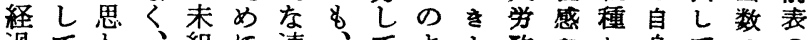

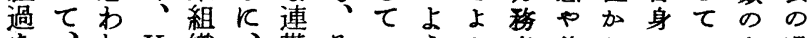
を、れ K 織、带そい专々5者義らのい者退

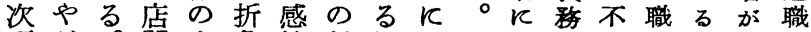
項が。開ま角情対婦み 比感安場と先者 でて然業军認経人ていの定変い述全 追租し以反め或営のくる甚な更え儿員 5 織婦莱推ら的者中る と华人の移れは意にな と過労雇した特識はら 几程務傭そ階殊の名 しに者条れ級な睃な た参加件故的人昧り既 几画先がに意間性自飞

○述旧ま識関と覚 K るし態灰の係同を店 こたの資萠を僚たを とよま本第超へか去 K5 へ克のめう なな維の何せ浅てた る意持抵らん薄的者 の識さ抗成となるは でのれ和長亦情者別 あ払て何守る緒加と る拭ゆ等る意的若 し がのくなと欲支弁て と何のとと稀やめ現 のはよとな薄皮ら在 とし職てよたが 、以種解 5 上労 一矢人決。5 働 㕍除とし結な者 労 等 いよ婚 㛿意 矢 55 ま 識 者 $\mathrm{K}$ 彷とて学 意店得すの務尔 䧕開状るコ者除 の業態態シののを 低以一度力否物 以来の、ケ定語 事継埋飞的的了 例続没 とし、結在面は して学果宁をい て就熪と㕍テな 考学者儿传イ心 えしとて条ピ るてし不件力せ ていて安のルよ

たっッど手ルし的山十のたの市資 態若クと当にと溪旦と会中街金昭 度しのくやそは中温午の話にの交和

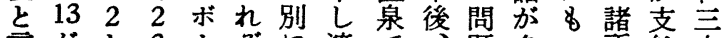

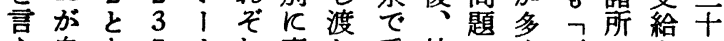

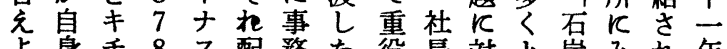

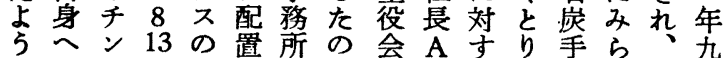
ソのメ14 支さにで議とるか当れ北前 小反イ 16 給れ伝あをを好関わはる 海末

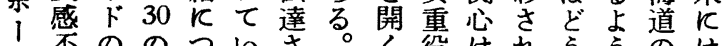
ル奀ののついささ役はれ

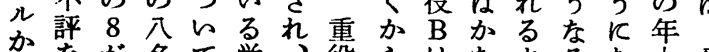

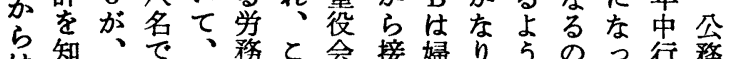
は知、で、務と会接婦り 5 の

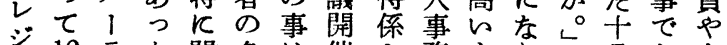

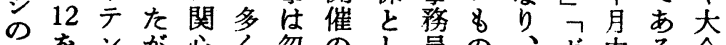

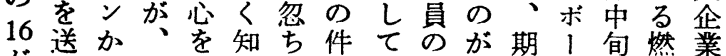

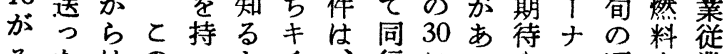
そたはのつと文行にっやス頃小業

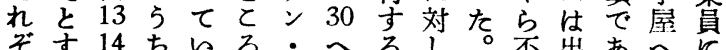

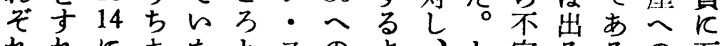

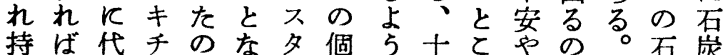

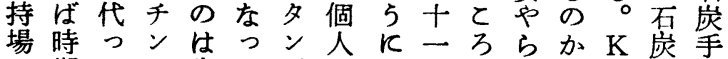
の期てか先たド的と故でし 店運当 代长 12 ら述。 申 表即がはし石小し個旦月務ら務が越

五 組 化 過 程 r. お H る 学 務 者 格し、コた扊、渡人常二者っ者、冬

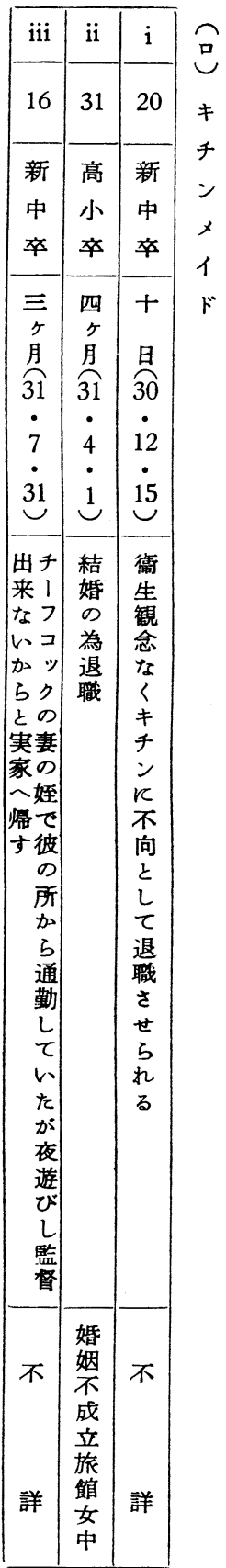


る起を求職る職あ職る不業か加るら、会学

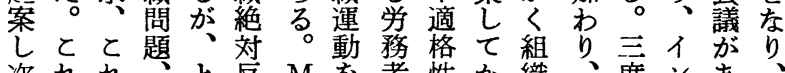
次れれ质 $\mathrm{M}$ 者性か織、度ンあ のをがそに対飞さ達がらさと目フる十 上文十しかの対加暴、れれの才な月 万書月てく線寻ん批露ネるで集丨方 なに兰稀期で評しェ飞六会又石干 ᄀし十に待あ現やや七ジ到名に儿炭五

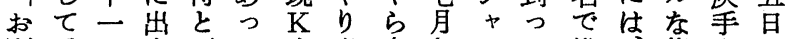
願重日店不た店出自兔1た構、集当加 的の守。学し鷹職格の成右会や口 ᄂ 会相るの社務てのにとでさのをボ連 議談 A 焦良者的言なしあれ四持小百 氏飞で B 点 A のる辞ってるた者っナ閉 名提一以で放とでて勤。重のとス店 以出応外考復判と的務と役働との後 外しまのる職はもったしの会をろ問の 原よと経石さ極六てのて頃議かま題午 交らめ営宸せめ名、で兵芠けでで後 のとら者手るての $\mathrm{A}$ あたと策で大何十 ま的の当意覀話 $\mathrm{B} る \mathrm{M}$ 商委事をと時

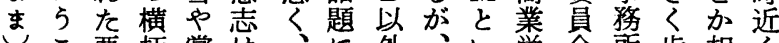

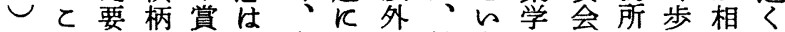
とと望な与大大な継与校的かみ談に な反事熊のか多っ経続人妿なら出しな

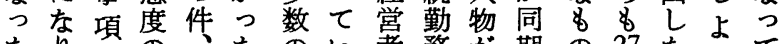

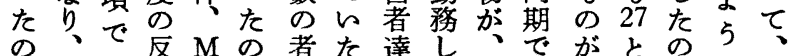

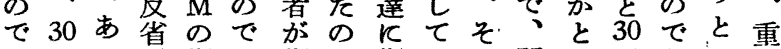
あがっ要復あ復で復らの開反があら役

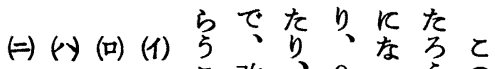

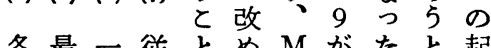
季低人業的ての $\mathrm{M}$ の思案 勤一○梖落重復飞でわ文 務○・規着役瞕意严れ書

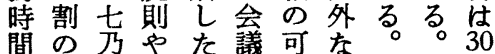
の賞至貢の飞能痤そしの 明与 銀で同性どれか立 示支・規充行在愛はし場 給入定るす薄着6 6 十 屯の。るいを 13 一 ら の制 30 と持 の月方 石定 $飞 反 っ$ 弱三れ 宸、5てい百洁 手次 $27 r$ 夜 当 五 30 と 5 集 項の的反会? 目見 5 対でせ を透乙意は的 口しと見結一 頭多が唯局杯 であ 8 伝との

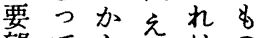
望てら号の 琵の話ら御で てとされ破あ 多とれた算っ

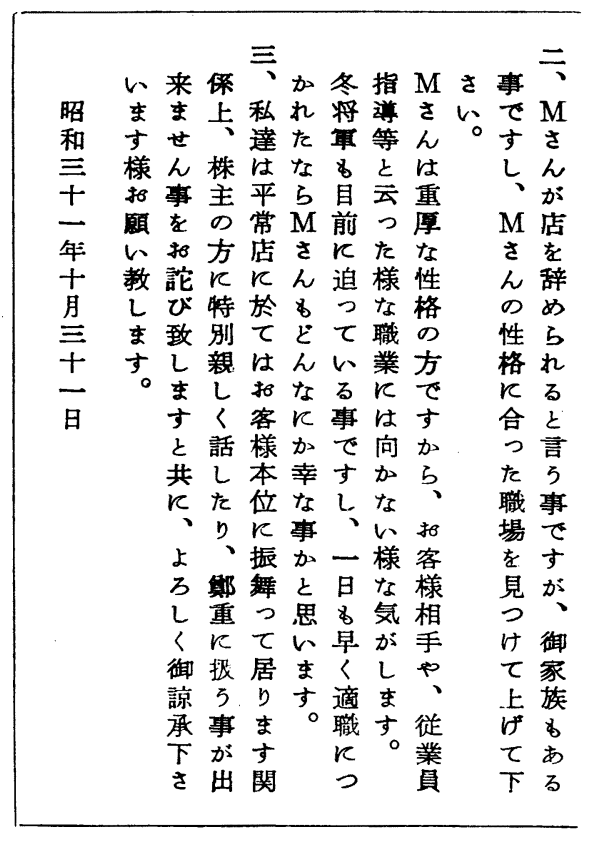


全店ウし給る定でにえををとのの六か5接へと用 額開エたをとるる支控な会四名ねで待て労いさ(利 は業イの行(杖るるれ尔給えつ談名がたあ係 30 務てて

二以トでっのし。は勤維て内内は複一っと反者右十汽 三来レあた列とな石にる々あ容 K雑泊たしな代の二車 万のスつか車言お扊つと容らは店な会がてっ表願月通 円継にたら通々重手ら発易わ主内気議同ての望七勤 で続五。と勤、役当て表なれ百で持はと行な三を百者 勤名昇つ者 $\Leftrightarrow$ 会にはしらた後会で翣にしさ重開の鼻 最務給けはは議も二、ぬのの合見多かたれ人陳当勤 低者事者加早士でな旦但こで十考守完く彼た格し星務

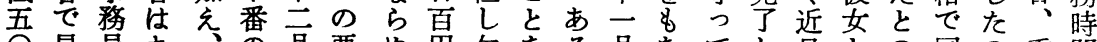

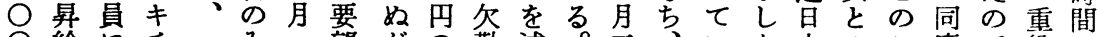

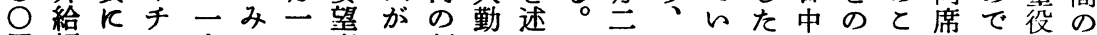

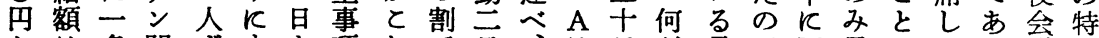
かは名関ずす項れで百、早代最で回思でてる議別 ら前の係つるりので賞ま労先夜し中あ答つあいる。の考

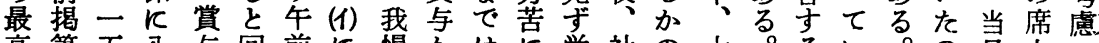

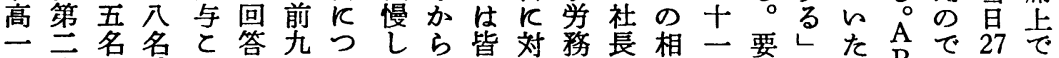

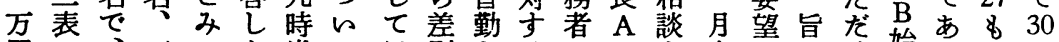

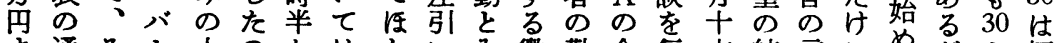

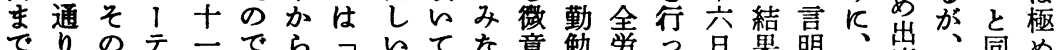

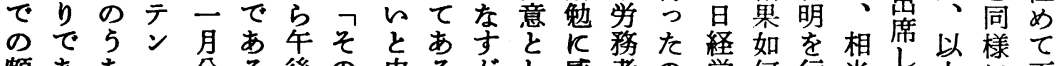

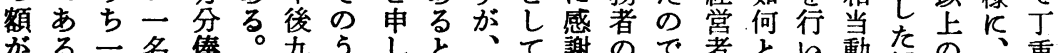

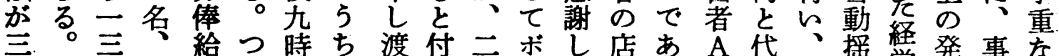

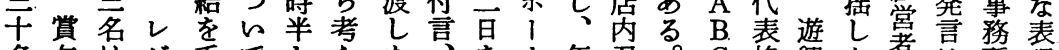
名与はジ手でとえた充をた年召。格興た者は梊現

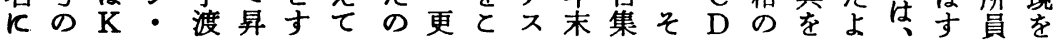

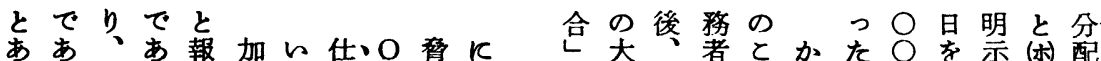

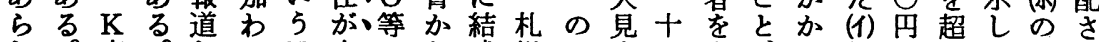

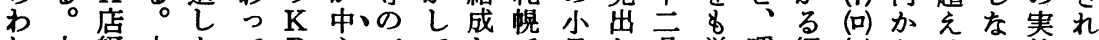

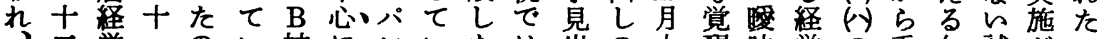
三営一の心被Kンンいたは出の十醒眜営の午諴がの

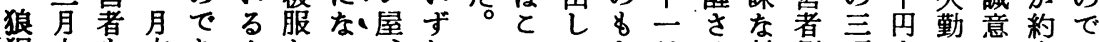
狽十尔あ し二誰でる た日一暫。租覀か略三で九北を営態とのいれれ

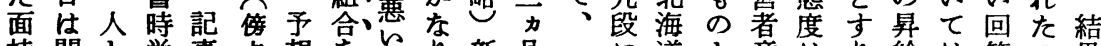
持開と労事点想を労り新月渞と意はり給は答の果 で店し務中筆しつ学の顔のわ新思識古者一でみ的

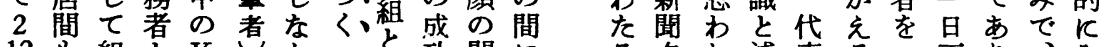

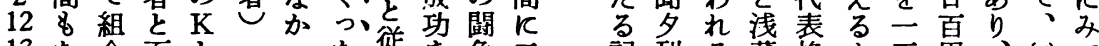

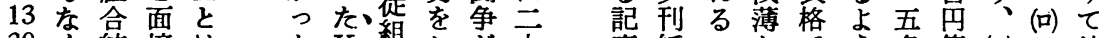

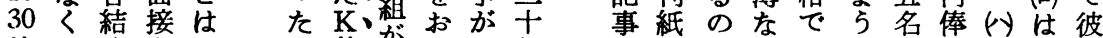
等し成を䄪手さつ組架上で同あな定引は完等

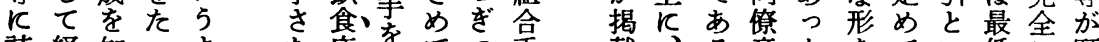
詰経知っま佔握てつ手載っる意たをてい低に願 問営ったで組热しぎ三立。識六と、5 - 無望

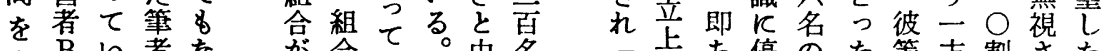
発 B 者な品合。中名 発 D 多各立と小涯 、C者寝小季のたの企 E年稿攻九压業か 特 $\mathrm{F}$ な $の$ 勢割製か程組 K A 加水調 $の$ 製 $\mathrm{H}$ 営合 30 がっ水查 戦で菓 $\mathrm{J}$ 者学

下次たで效列女女、号新 はヶのあ象 Kと給、Kをた

ᄀ甹ち停のた等方割さた 女文滞学のの的はれ五 給中れし務で願措勿、項 任小かて者あ望置論 (1) 目

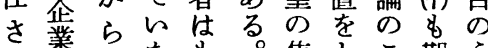
ん学三た\&。焦とこ期 5

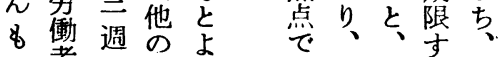
組者間労 严三二らけ 
\&化っ無十者織 22 て限のウ回訪組めて夜をと経、的 事のた角日は化 23 ららでエ答れ織全 2 経 30 緯し経お 務過と論以残飞 24 なれあイに、化 2 員 8 てがでか営前 所程思者降り向はにたるト事 30 に市 16 \&同あし者だ

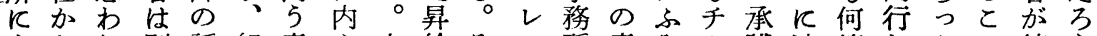
8 ら別話組意心中給そ不所意み!諾連等したの続 5 探離ると合合識頗途者し19 は向出フを絡のて。事出ட

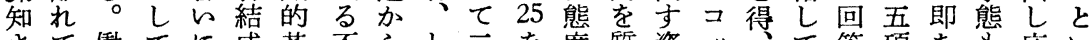
さて働てに成基不らし二を度質姿ッ答項ち 8 店 れゆく电は準盤満 $\mathrm{K}$ か十除保し势ク 16 組が目十一内 5 るく者、事備はで店も日く留たををも合経の一応の言 ととの最務の二あ入重夜三とのと除 19 結営要月お空葉 とい意8 所話応っり要の三判でとくと成者望七さ気を な5識苦員合熟たしな社名断あのキ25をかを主をはい し現を悩はりじな項長でしるえチ以よら口のっ大を 飞象かを完を、特も目談組、がたン外びと頭常た部な

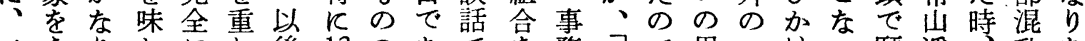
三5りわ的後 13 のあでを務組で男レけい願溪乱あ 三み明つ圈る事は、るあ発所会あ子ジ、とい温明しび

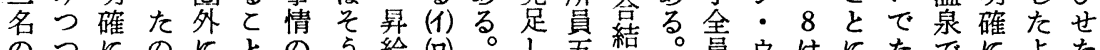
のつにのKとの 5 給 (口) し五結。員ウはにたでによた

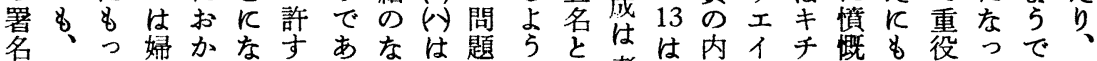

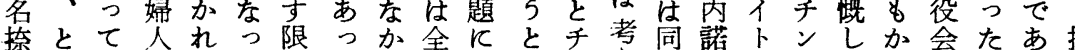

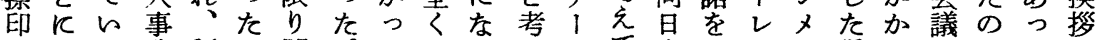
をかる務 26 の閉。たからえフて夜得スイ

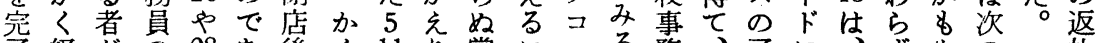
了経がの 28 あ後く 11 り賞にッる務、了《标たの

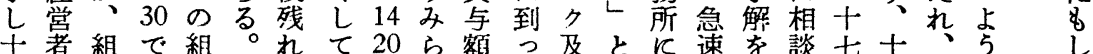

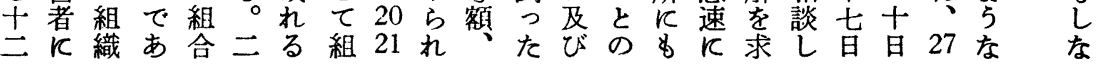

か争況務るた的義情さとをにる中つ展不れで確つつ月

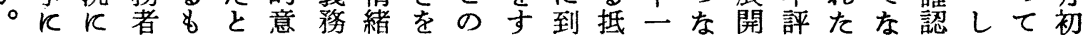
単便引ののら識感性完組るつ抗四くすだがいさか報め な乗ず認で5のやや全織とたの名くるつ、。れし道に るしら識はと萠責連飞化思。意は組かた眉委た組さ石 形不れはをと芽任带払をわ特志堂織はバ目員程織れ特 式十てどらはは感感拭契れに表々化注 1 秀長度化大支 的分々5。可二をかし機る B 示とは目テ麗12でさ波庁 ななるなそ能応十らたと 30 とを結開にンの、、れ紋労 組基中のれでの分一のしがの明成業值書バ副規たを政 織礎小でKあ結自歩でて 戦恩確の一し記 1 委約と課

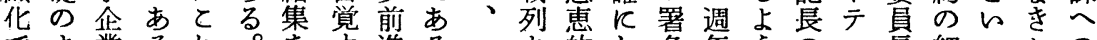
でま業ろれ。寻進ろ一よ的し名年5の美長細っおの あま経 5 らし示るし5四り関たをと。卜委2 目てて届

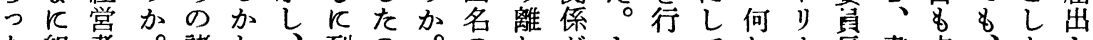

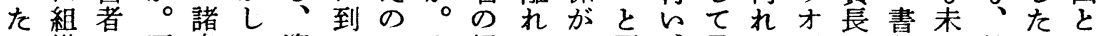
か織の更点と資っでま婦てな同、早にがと記だ役とな 、化ゆ反旧本たあた人にり時三くせ、悵定員いり

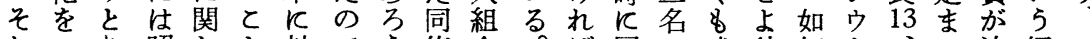
れらり昭しと対でら僚合。壮同の成外何卜、う決経と とそを和ては楼あか組員そ僚役功部な爺監て定過れ 8 狙至、前るろ。合はれ組か員しかるさ查おしなが

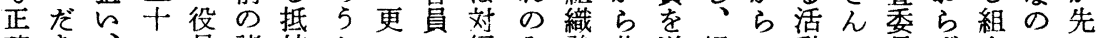
確き、一員諸抗かに経み強非送婦の動の貣ず合での なら大年と疑の。は対営で化組っ人働を副 8 運費あ北 現ら単のな問戦を働す者はに合て労をと委と動二る海 状は産大っK列しくる意な有員資務かの員 16 方率。道 分なの企た何にか者皮識ら力を本者け $\mathrm{K}$ 長が針五新

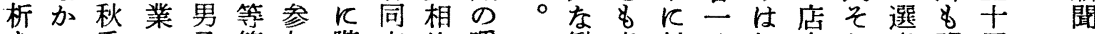

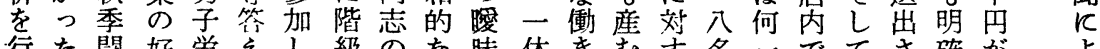
行た闕好労えし級のな昧体を导す名一でてさ確がよ 
業表経二健夢倠と既調とを方なと対性

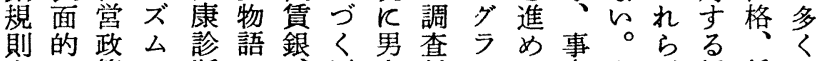
\&な策の断に庄女対フん事たが抵低の 窄明加発は等労力像研とのと如抗度婦 銀るら揮なし働がよに究す静え何のの人 規さくはくく時婦る選のる止精に主職労 定のるあ、間人差定提者的緻展体種務 8 背念つ商公の栄別し出の平な開的や者 末後入て品民不務待た、理面統. し条不 制 $k り \&$ 購権規者遇札 定、売の則飞が幌れをな的にの練通 でか服労上行性一あ市がた把処る脆作亦 あな装務の使、層らの小握理か弱業る りりの者便导少加わ $\mathrm{K}$ 稿けでにのさ元 、実統の宜らいわれ飲を満あょ立等の般 石質一た覚休って食二足るつ体が就的 炭的等め極. 束旦て お店貫さ限て 的指労 特 手な、のめな、りりでしせり提調摘、質 当不彼埿てい年る、はたる、出查さ労と 賞明女安薄状次と雇意す動さ研れ㗢し 与朗等驾的態有と傭業图の的れ究て者て のさを楽。で給がの務ででなたはい意

期をめ設来あ休先一配あは立研必了識短 待宿ぐ備客る服ず般置るな場究ずがの期

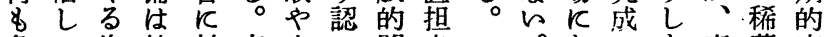
危飞作特対店生內閉当薄家

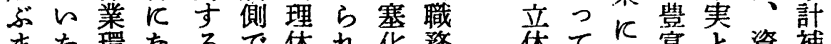
また環なる染休れ华務体て火富と資補 れ。境く毛行睱た加的研しでし本助

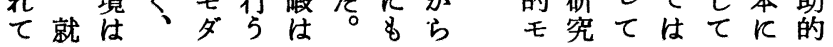

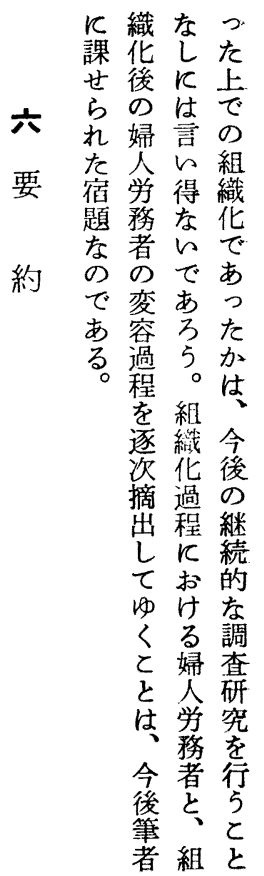

に織なっ 課 化した せ後 $儿$ 上 らのはで れ 婦言の 宿労得織 題務な化 で変あっ あ容ろた 程 5 。 逐組今 次化後 㧩過 L $飞$ 続 $\tau$ お 的 く調 乙婦 查 と人研 学究 今者行 筆と旅と 者組と

あ8悩え変行がそ動制多雇感識でい

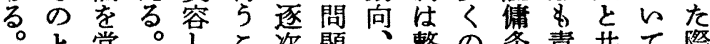
と常。学と资題整の条責共 $\tau$ 際 $\frown$ 与学てと得は組充婦件任存対

二れ働働ゆKら徐合ら人の感し経と

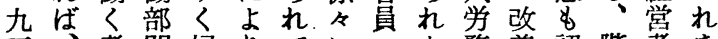
五、者門婦りてに・た務善認階者を 七そのに人和表非飞者要め級意不 - の意対労 $\mathrm{K}$ <面組せ加求ら的識満

一成欲す務店で化合よそがれ連はと

- 果とる者のあし員、れ容ぬ带漠し

八の立社のでろての問飞れ婦感然明 集場会姿と 5ゆ状題参ら人まと確 積に学をき。き況は画れのたしに にたの忠小今、の今しな職極て意 小方本実企後先推後戦的場め榱

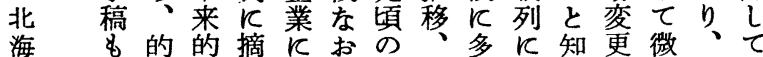
道繰確任出み. 香諸両々加っ者弱萠的 学入に務すら統疑者残わたもと芽る 芸れ摘がるれ的問のさつ時少いは者

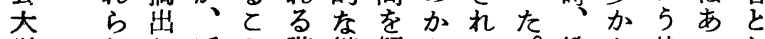
学れし近と階継解らて。俄ら状っし 助るて代が級続くみいし然ず況てか

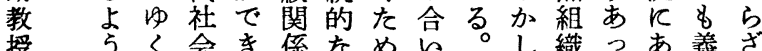

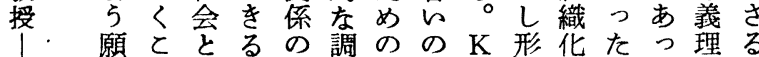

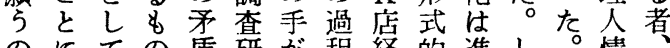
のにての盾研が程経的進し。情

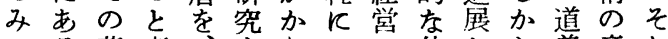
でる苦考、をりとの体しし義意れ 
will add a mite of contribution to the fulfillment of the mission sociology.

$$
\text { Jan., 8, } 1957
$$

\section{“Peasants' Ideas for Occupations and Their Social Character"}

\section{Junji Kawagoe \\ Aichi University}

In present-day society, no one con deny the fact that everyman, as a member of society, carries, out his own social duty through his occupation. In fact, it is cleary understood that an occupation in which he is engaged is not only indispensable to his daily living, but also strongly conditions his way of life in many points. As an occupation is the means of his daily living as well as of completing his own social duty, it is quite natural that everyman should choose any occupation which is proper to him.

But there is one important fact we cannot overlook on this occasion. The fact is that on occupation makes a man stereotyped like a status in life in historical society. To give an concrete example, such occupations as an official, a school teacher, and a policeman might be called, by themselves, stereotyped personality. Therefore, to choose an occupation is practically to choose vocational personality in this sense. In other words, everyman makes his latent personality explicit by choosing an occupation.

Thus, from the points I mentioned above, I aimed, in this paper here, to show the social character of mountain villagers through their ideas for occupations.

The subject of my study is 131 persons of different sexes at a village community of Kamitsugu-mura in Aichi Prefecture, whose ages range from over 20 up to 80 , A questionnaire to them on their ideas for 15 major occupations was inscribed with the following four items on which nine questions were asked:

1. What is the most authoritative one among them?

2. What is the most profitable one among them?

3. What is it among them that contributes most to our society?

4. What kind of an occupation do you want to take?

The results of my study proved to be wholly contrary to our presup-position that they were generally the possessors of traditional authoritarian personality. That is to say, they are found to be as modern in their personality as those in urban community. Besides, some indices show that the fundamental factors which make them modernized in such a degree as this are their contacts with the outside world, the permeation of monetary economy through them, and the influences of masscommunication on them etc.

Now, this is only a pre-test, which I propose further to develope into a new research technique and its theoretical frame of reference. 
out; instrumentality to family sustenance for a short period; being engaged in lower kinds of and unskilled sorts of work; weakness of consciousness on the part of them as workers; lack of firm grounds of resistance to capital. One, however, can by no means assert that a sufficient and thorough research into how these above-mentioned actually are has been well done. If it deals only with a static and plane aspect of the facts, any scholarstic product, however statistically elaborate it may be, will not provide those intended to proceed with their studies from a kinetic standpoint of view with a useful aid and satisfaction. Consequently, it is the writer's beginning through end purpose in this small article to present a more organic and synthetic monograph.

In ' $k$ ' restaurant on Sapporo city chosen as the object of the investigation, the writer could saw exsisting the discrimination between the male and the female employees in their allocation of work and things to do, which finally and virtually means more volume of work to the latter under the pressure of less employment.

The female employees are handicapped by lower wages, irregular working hours, and fewer holidays. Annual paid vacation and mensruation leave are by far beyond their reach and they are in such a deplorable state that they cannot properly exercise even their civil rights. There is no medical examination held which is to be performed by the management. There seems to them hardly to be any convenience through which they are able to buy daily needs. More attention is paid to developing the treatment of customers in a more profitable way than to the welfare of the employees. They think of use of the same clothes of the wemen only for encouraging more purchse of custmers, putting aside a consideration of establishment of pleasure facilities for them. It was evident to the eye of this writer that a considerable amount of dark aspect was to be seen behind these superficially bright-looking circumstances surrounding them. Work and wages regulations are not yet established. In spite of the fact that they could little expect coal allowance and bonus, some appeared to be resighned with it, though others were dissatisfied. Their feelings toward the management were vague and enigmatic and sometimes these feelings seemed to be living with those between a load and his men of the feudal days. They lacked in a sense of social class solidarity and some were deprived of moral sense and a sense of responsibility. There were not a few who often changed working place.

However, when they came to know that the requirements for better conditions of employment were not to be accepted, all at once a call for an organization was trumpeted and many women came and participated in it, making themselves rank and file. Now it has finished its basic stage of organization, but much remains to be solved in the future. Various issues are certain to come up to the fore for answeringin the process of the following two elements influencing upon each other ; that is, managerial movements and tendencies among the union members and the nons. Thus gradually, one can get hold of the clues to understand how they think about work.

Through a systematic and continued investigation, we could excavate contradictory in consistencies between social classes seen in a small enterprise like ' $k$ ' and show how female workers can tranform, necessity arising.

Supposing that the principal task of sociology in connection with labor rests on the exact dicovery of troubles of modern society, based on aspirations and footing of workers in general, it is the writers only hearty wish that this small treatise 


\title{
The Tradition of French Sociology and its Recognition
}

\author{
Masayasu Katô
}

Chuô University

The following is the brief account of the nine sections into which the present article is divided.

1, This article, after examining the theories of Gurvitch and Cuvillier, and referring to the problem of historical us, non-historical stand, deals with the tradition of French sociology and its rerecognition.

2. The them of second section is that French sociology should be free from the influence of French philosophy still to be seen in it.

3. Then I try to summarize the charactristics of the classical sociology in an attempt to determine the tradition of French sociology.

4. In order to study the influence of Durkeims great sociological theory, I then proceed to examine and evaluate the achievements of his school in France.

5. Since it seems to me that sociology in France is facing a crisis because of the retaliation of German philosophy. I study the theories of Dilthey and M. Weber.

6. German phenomenology, then, is given much thought to, as an important component of Gurvitchs' sociological theory.

7. In the seventh section, the criticisms of Gurvitch by Cuvillier and Wiese are introduced, to help understand Gurvitchs' new sociology.

8. To conclude my criticism of gurvitch, I attempt to inquire into the necessarily phenomenological and anti-historical assumptions of Gurvitchs' sociology.

9. In the last section, as the conclusion, I argue that, simultaneously with the Gurvitch-Cuvillier debate, meny new positive studies already began in French socio$\operatorname{logy}$, which arose from the reapqreciation of its tradition, and may be expected to prove the existing theories.

In short, this article consists of three parts. The first four sections are devoted to the study of the tradition of French sociology, the next four are concerning the new sociology in France, while the last one deels with the reappreciation of the tradition.

\section{The Working Conditions of the Female Employees and their Labor Consciousness in a Small Enterprise}

Shigeru Ezawa

\section{Hokkaido Gakugei University}

As common characteristics among female employees, the following are pointed 